\title{
Which Traits Influence Bird Survival in the City? A Review
}

\author{
Swaroop Patankar ${ }^{1, *}$, Ravi Jambhekar ${ }^{1}$, Kulbhushansingh Ramesh Suryawanshi ${ }^{2,3}$ and Harini Nagendra ${ }^{1}$ (D) \\ 1 Center for Climate Change and Sustainability, Azim Premji University, Bengaluru 562125, India; \\ jambhekarm@iisc.ac.in (R.J.); harini.nagendra@apu.edu.in (H.N.) \\ 2 Nature Conservation Foundation, 1311, 'Amritha', 12th A Main, Vijayanagar 1st Stage, Mysore 570017, India; \\ kulbhushan@ncf-india.org \\ 3 Snow Leopard Trust, 4649 Sunnyside Avenue North, Suite 325, Seattle, WA 98103, USA \\ * Correspondence: swaroop.patankar@apu.edu.in
}

Citation: Patankar, S.; Jambhekar, R.; Suryawanshi, K.R.; Nagendra, H. Which Traits Influence Bird Survival in the City? A Review. Land 2021, 10, 92. https://doi.org/10.3390/ land10020092

Academic Editors: Alessio Russo and Giuseppe T. Cirella

Received: 26 November 2020

Accepted: 19 January 2021

Published: 20 January 2021

Publisher's Note: MDPI stays neutral with regard to jurisdictional claims in published maps and institutional affiliations.

Copyright: (c) 2021 by the authors. Licensee MDPI, Basel, Switzerland. This article is an open access article distributed under the terms and conditions of the Creative Commons Attribution (CC BY) license (https:// creativecommons.org/licenses/by/ $4.0 /)$.

\begin{abstract}
Urbanization poses a major threat to biodiversity worldwide. We focused on birds as a well-studied taxon of interest, in order to review literature on traits that influence responses to urbanization. We review 226 papers that were published between 1979 and 2020, and aggregate information on five major groups of traits that have been widely studied: ecological traits, life history, physiology, behavior and genetic traits. Some robust findings on trait changes in individual species as well as bird communities emerge. A lack of specific food and shelter resources has led to the urban bird community being dominated by generalist species, while specialist species show decline. Urbanized birds differ in the behavioral traits, showing an increase in song frequency and amplitude, and bolder behavior, as compared to rural populations of the same species. Differential food resources and predatory pressure results in changes in life history traits, including prolonged breeding duration, and increases in clutch and brood size to compensate for lower survival. Other species-specific changes include changes in hormonal state, body state, and genetic differences from rural populations. We identify gaps in research, with a paucity of studies in tropical cities and a need for greater examination of traits that influence persistence and success in native vs. introduced populations.
\end{abstract}

Keywords: urbanization; birds; ecosystem services; survival; adaptations; traits

\section{Introduction}

Today, urbanization presents a major threat to biodiversity [1,2]. By 2050, 68 percent of the world's population will live in urban areas [3]. As urban settlements increase, the landscape undergoes drastic change from its pristine state [4]. However, ecologically speaking, urban areas are highly modified and fragmented habitats, in the form of several managed and unmanaged urban green spaces, like public and private garden, nature reserves within the city, vacant plots, to name a few, which are capable of providing resources to a small number of highly adaptable species of fauna [2,4-6]. Not only resident, but several migratory, species make use of this urban habitat [7]. The urban avian community is composed of introduced and invasive species and highly adaptable native species $[8,9]$, although Aronson et al. [8] observed that the community is dominated by locally adapted species, with only five percent non-native species. The urban greenspace along with the biodiversity it harbors, forms a unique ecosystem within the human dominated landscapes, capable of providing several ecosystem services to the cities [2]. Ecosystem services are the services that are beneficial to humans as a result of naturally occurring processes [10], which render them all the more important in human dominated landscapes, like cities.

Birds, which are some of the most successful urban adapters, provide a range of ecosystem services. Birds, in general, are capable of significantly affecting ecosystem processes, due to their specific characters, like flight capability, high metabolic demand, which leads to tolerance to discontinuous food sources; and, flock formation, which significantly affects 
ecosystems processes, like nutrient cycling [10]. The urban bird community structure also acts as an indicator of the structure and functionality of urban areas as habitats [11]. In this study, it was found that habitat specialists, like woodpeckers and hole-nesting birds, occurred in the peripheral areas of the city, indicating healthier vegetation cover, while habitat generalists increased near the city center and residential areas with less vegetation cover.

Birds have been found to provide all four types of ecosystem services that were mentioned in the UN millennium ecosystem assessment, namely, regulatory, provisioning, supporting, and cultural [10]. Urban birds provide regulatory services by acting as pest control agents when they feed on disease causing insects, prey on rodent population, and scavenge on garbage; provisioning services by acting as seed dispersers when they ingest fruits, which helps in plant regeneration; and, supporting services by acting as nutrient recyclers via their excretory products $[12,13]$. However, urban birds perhaps play the most crucial role in providing various cultural services. One of the most important services rendered by urban birds is to act as a connecting link between the natural environment and the increasingly nature deprived urban denizens [7]. Birds in residential neighborhoods in cities are generally valued for their color and songs, for providing mental and physical wellbeing, as indicators of seasonal change, for education, and for giving sense of familiarity, by the residents $[7,14]$. Birds are also an inspiration for art, recreational activities, like birdwatching and wildlife gardening [10]. In India, it is a tradition of grain merchants to give a small portion of their goods to granivorous birds, like house sparrows (Passer domesticus), as an offering for prosperity in business. In the city of Delhi in India, it is a common practice of offering meat to scavengers, like black kites (Milvus migrans) as religious practice, due to which the black kite population dynamics in the city is significantly affected [15].

It is abundantly clear that the conservation of these ecologically important fauna in urban landscapes is crucial. Many cities are now experimenting with the management of urban green spaces for conservation and, there have been numerous studies on the effect of such management interventions on bird ecosystem services in cities [13]. However, for such management practices to be entirely successful, it is also important to understand the uniqueness of birds who call this urban habitat their home. One is then compelled to ask what characteristics sets apart the birds able to adapt to this unique habitat from those who disappear from it? It would be counter-intuitive to the purpose of conservation if such measures are taken without understanding the changes in "traits" of urban birds.

Studies on trait changes have grown in recent years, as researchers begin to focus on the study of urban areas as modified habitats. It has been suggested that studying the traits of urban biodiversity could be a more effective approach for preserving the ecosystem functions and services in urban areas, ss such data provide authentic and useful information to urban planners [12]. Birds comprise the taxon that is perhaps the best studied in cities. Birds constitute especially useful model species for studying trait changes, as they respond to changes rapidly, are of interest to naturalists and the public at large, are easy to monitor, and they show measurable changes. They have hence been studied widely in the urban context $[16,17]$.

McKinney et al. [1] conducted the last comprehensive review assessing diverse trait changes that were observed in urban birds. In general, only certain species, which are characterized by specific traits or combinations of traits, seem to be more capable of coping with the environmental alterations that are imposed by urbanization [18]. This capability might differ according to season, geographic region, or city structure [9], but such species of urban utilizers can tolerate a wider range of environmental conditions [19] and they appear to exhibit similar characteristics globally [20,21]. The research on bird adaptations to urban habitat has since expanded considerably. Many researchers have carried out reviews and meta-analyses of specific trait changes, including behavioral traits [22,23], community traits [21], and physiological changes [24]. However, there is a need for an updated comprehensive review that collates and synthesizes existing information. 
This paper reviews research studies on traits that influence the survival and response of birds to urbanization, based on a literature review of research that was conducted between 1979 and 2020, identifying the state of current knowledge, highlighting key knowledge gaps, and identifying geographic and species-specific disparities in research that require specific focus. The specific aim of this study was to synthesize the information available on studies when comparing urban and rural birds while taking a trait-based approach. Finally, we highlight the gaps in knowledge and pinpoint future directions for research.

\section{Materials and Methods}

We listed and categorized the traits that are described in birds referring to the review paper by McKinney [1] and making additions of our own. The traits were selected with the knowledge that they were essential for basic survival and reproductive success of birds. To begin this review, we conducted an intensive literature search for each trait, using Google Scholar during August 2019, based on combinations of the following keywords: "urban", "birds", "urbanization", "impacts", "traits", "changes", "effects", "behavioral”, "physiological", "functional", "diversity", "global", "avifauna", "song", "life history", "nesting", "foraging", "generalist", and "specialist". Each publication that resulted from this search was reviewed to determine whether it met the criteria for inclusion. The basic criterion was that the study had to be either a comparative field study or an experimental study looking at effects of urbanization in an urban-rural gradient on bird communities or a single bird species. The literature was searched by its importance and relevance to the key words used. Review papers and experimental studies were included as a part of this study. The reviewed papers were grouped into five broad trait groups: ecological traits, which included traits pertaining to ecological niche and community interactions; life history traits, which included traits that are related to reproductive success, breeding cycles, and overall survival; physiological traits, which were related to the physiological, endocrine, and morphological changes in the birds in urban areas; behavioral traits, which were the changes in important behaviors, like singing, fear responses, innovative behavior, to name a few; and finally, genetic traits, which were the trait changes in the genetic structure of urban birds (for complete list, refer Supplementary Materials Table S1). Each paper was read and categorized based on the methodology used, the results, and interpretations of the study. Knowledge gaps and scope for further research were documented.

\section{Results}

A total of 226 publications were finally included for review (Supplementary Materials Table S2). The earliest paper that we found was published in 1979. The field has grown rapidly since then, with research on several different traits (Figure 1; Table 1). The interdisciplinary nature of the topic has led to an expansion in the number of journals publishing urban ecological research (Supplementary Materials Figure S1). Behavioral Ecology published the most papers on trait adaptations in urban birds, followed by Urban Ecosystems, PLoS ONE, and Scientific Reports (Supplementary Materials Figure S1). Many of the trait changes have been studied on large bird communities at the regional or global scale. Song birds and water birds are well studied, and most of our understanding of impact of urbanization comes from these guilds of birds (Table 2). Additionally, some bird species such as Eurasian blackbird (Turdus merula) are widely represented in the literature as compared to others. Studies from temperate countries dominate the literature, with only a few studies from the tropics (Figure 2). 


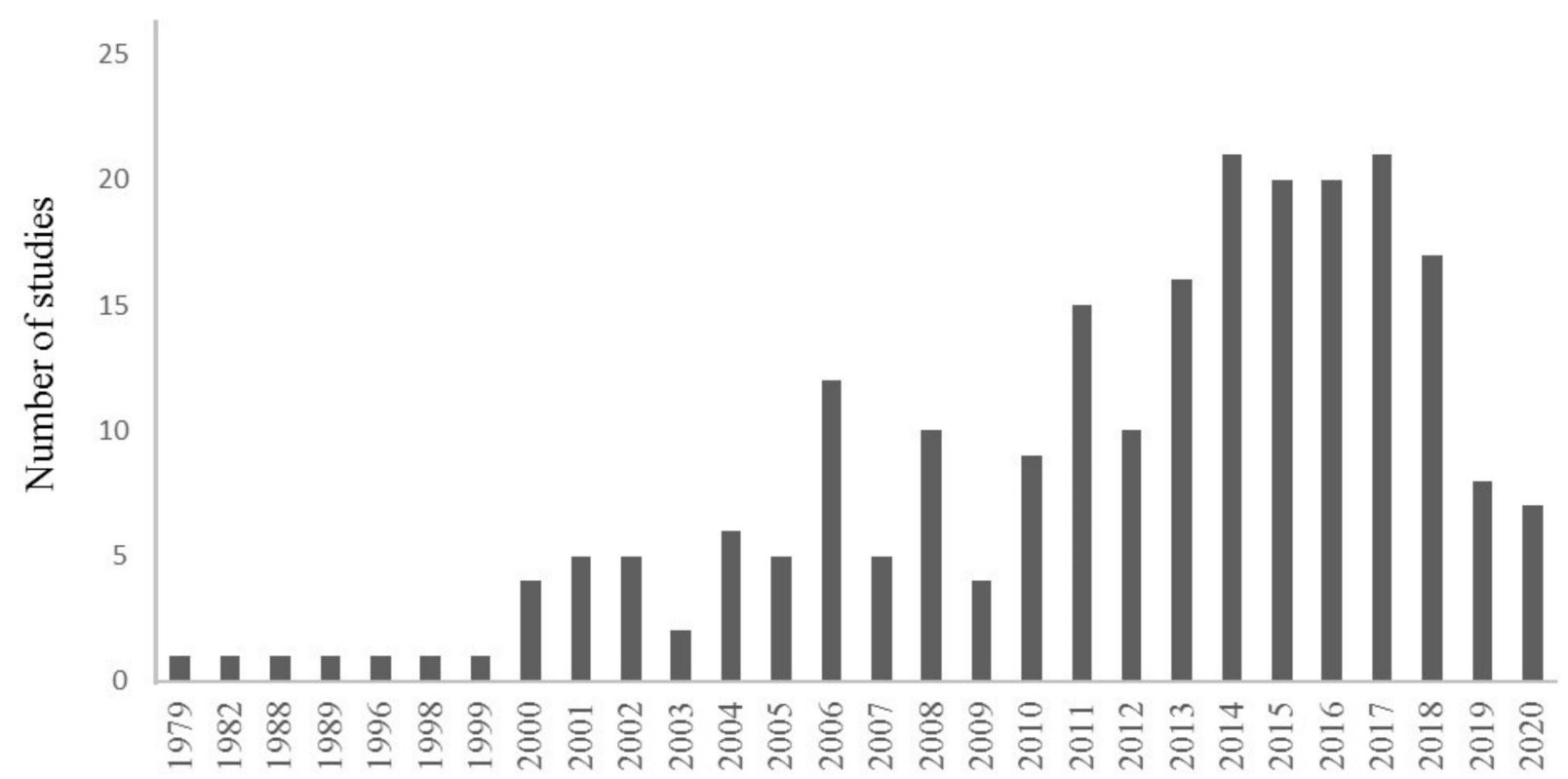

Timescale (in years)

Figure 1. Number of research papers on urban bird traits related to urbanization from 1979 to 2020.

Table 1. Number of published articles on each of the bird traits included for this review along with the number of studies on individual species ( $<4$ species) or large communities ( $>4$ species).

\begin{tabular}{|c|c|c|c|}
\hline Trait Studied & $\begin{array}{l}\text { Number of Studies } \\
\text { (<4 Species Studied) }\end{array}$ & $\begin{array}{l}\text { Number of Studies } \\
\text { (>4 Species Studied) }\end{array}$ & Total \\
\hline \multicolumn{4}{|l|}{ Ecological } \\
\hline Diversity & 1 & 14 & 15 \\
\hline Nesting spaces & 7 & 9 & 16 \\
\hline Abundance & & 8 & 8 \\
\hline Richness & & 10 & 10 \\
\hline Diet breadth & 1 & 9 & 10 \\
\hline Generalist-specialist & 5 & 7 & 12 \\
\hline Distribution pattern & 1 & 3 & 4 \\
\hline Density & & 3 & 3 \\
\hline Migration & 4 & 3 & 7 \\
\hline Habitat dependence & 1 & 4 & 5 \\
\hline Dispersal & & 1 & 1 \\
\hline Sociality and sedentariness & & 1 & 1 \\
\hline Community composition & & 1 & 1 \\
\hline Habitat preference & 2 & & 2 \\
\hline \multicolumn{4}{|l|}{ Life history } \\
\hline Reproduction cycle & 3 & 2 & 5 \\
\hline Clutch size & 5 & 4 & 9 \\
\hline Nesting success & 4 & 2 & 6 \\
\hline Breeding timing and/or performance & 2 & 1 & 3 \\
\hline Brood size & 2 & 2 & 4 \\
\hline Fecundity and adult survival & 2 & 1 & 3 \\
\hline Activity time range & 1 & & 1 \\
\hline Migration & & 1 & 1 \\
\hline Fitness & 1 & & 1 \\
\hline \multicolumn{4}{|l|}{ Physiological } \\
\hline Reproductive physiology, circadian rhythm and migration & 12 & 12 & 24 \\
\hline Brain size & 1 & 5 & 6 \\
\hline Body size and/or mass & 5 & 4 & 9 \\
\hline Inflammatory response, oxidative stress & 1 & 2 & 3 \\
\hline
\end{tabular}


Table 1. Cont.

\begin{tabular}{|c|c|c|c|}
\hline Trait Studied & $\begin{array}{l}\text { Number of Studies } \\
\text { (<4 Species Studied) }\end{array}$ & $\begin{array}{l}\text { Number of Studies } \\
\text { (>4 Species Studied) }\end{array}$ & Total \\
\hline Stress physiology & 10 & 1 & 11 \\
\hline Endocrine traits & & 1 & 1 \\
\hline Bill length & 2 & & 2 \\
\hline Plumage coloration & 1 & 1 & 2 \\
\hline \multicolumn{4}{|l|}{ Behavioral } \\
\hline Fear and stress responses & 17 & 10 & 27 \\
\hline Foraging behavior innovation & 6 & 6 & 12 \\
\hline $\begin{array}{c}\text { Innovation, learning and problem-solving ability, Neophobia } \\
\text { and risk assessment }\end{array}$ & 10 & 5 & 15 \\
\hline Entire song structure & 7 & 3 & 10 \\
\hline Song frequency and/or amplitude & 16 & 1 & 17 \\
\hline Aggression & 11 & & 11 \\
\hline Dawn chorus & 1 & & 1 \\
\hline Call frequency, amplitude & 2 & & 2 \\
\hline Song frequency, bandwidth & 2 & & 2 \\
\hline Song syllable & 1 & & 1 \\
\hline Song timing & 1 & & 1 \\
\hline \multicolumn{4}{|l|}{ Genetic } \\
\hline Gene expression & 2 & & 2 \\
\hline Genetic changes & 1 & 1 & 2 \\
\hline Genetic divergence & 1 & 1 & 2 \\
\hline Total & 148 & 139 & \\
\hline
\end{tabular}

Table 2. Bird families represented in the literature studying urbanization induced trait changes. Bird community studies comprise of global reviews or analysis of global datasets, while individual family studies comprise of local datasets and experimental studies.

\begin{tabular}{|c|c|c|c|c|c|c|c|}
\hline Bird Family & Common Name & Ecological & Life History & Physiological & Behavioral & Genetic & Total \\
\hline Bird & & & & & & & \\
\hline $\begin{array}{c}\text { community (>2 } \\
\text { families) }\end{array}$ & & 58 & 7 & 15 & 29 & 2 & 111 \\
\hline Turdidae & Thrushes & 1 & 1 & 8 & 8 & 2 & 20 \\
\hline Passerellidae & New world sparrows & & 1 & 7 & 11 & & 19 \\
\hline Paridae & Tits & & 3 & & 11 & 2 & 16 \\
\hline Passeridae & Old world sparrows & & & 3 & 5 & & 8 \\
\hline Fringillidae & Finches & & & & 6 & & 6 \\
\hline Cardinalidae & Cardinals & & & & 4 & & 4 \\
\hline Corvidae & Crows & 1 & 1 & 1 & 2 & & 5 \\
\hline Strigidae & True owls & 3 & 1 & & 2 & & 6 \\
\hline Zosteropidae & White-eyes & & & & 4 & & 4 \\
\hline Accipitridae & Accipiters & 2 & 4 & 1 & 4 & & 11 \\
\hline Mimidae & Mimids & & & 2 & 1 & & 3 \\
\hline Rallidae & Rails & & & & 3 & & 3 \\
\hline Emberizidae & American sparrows & & & 2 & & & 2 \\
\hline Muscicapidae & Old world flycatchers & & & & 2 & & 2 \\
\hline Sturnidae & Starlings & & & & 2 & & 2 \\
\hline Troglodytidae & Wrens & & & 1 & 1 & & 2 \\
\hline Tyrannidae & Tyrants flycatchers & & 1 & & 1 & & 2 \\
\hline Tytonidae & Barn owls & 2 & 1 & & & & 3 \\
\hline Artamidae & Crows & & & & 1 & & 1 \\
\hline Columbidae & Pigeons and doves & & & & 1 & & 1 \\
\hline Corcoracidae & Australian mudnesters & 1 & & & & & 1 \\
\hline Falconidae & Falcons and caracaras & 2 & 3 & & 1 & & 6 \\
\hline Icteridae & Songbirds & & & & 1 & & 1 \\
\hline Laridae & Gulls & & & 1 & 5 & & 6 \\
\hline Meliphagidae & Honeyeaters & & & & 1 & & 1 \\
\hline Monarchidae & Monarch flycatchers & & & & 1 & & 1 \\
\hline Nectariniidae & Sunbirds & & & 1 & & & 1 \\
\hline Thraupidae & Tanagers & & & & 1 & & 1 \\
\hline Pandionidae & Ospreys & & & & 1 & & 1 \\
\hline Haematopodidae & Oystercatchers & 1 & & & & & 1 \\
\hline Total & & 71 & 23 & 42 & 109 & 6 & 251 \\
\hline
\end{tabular}




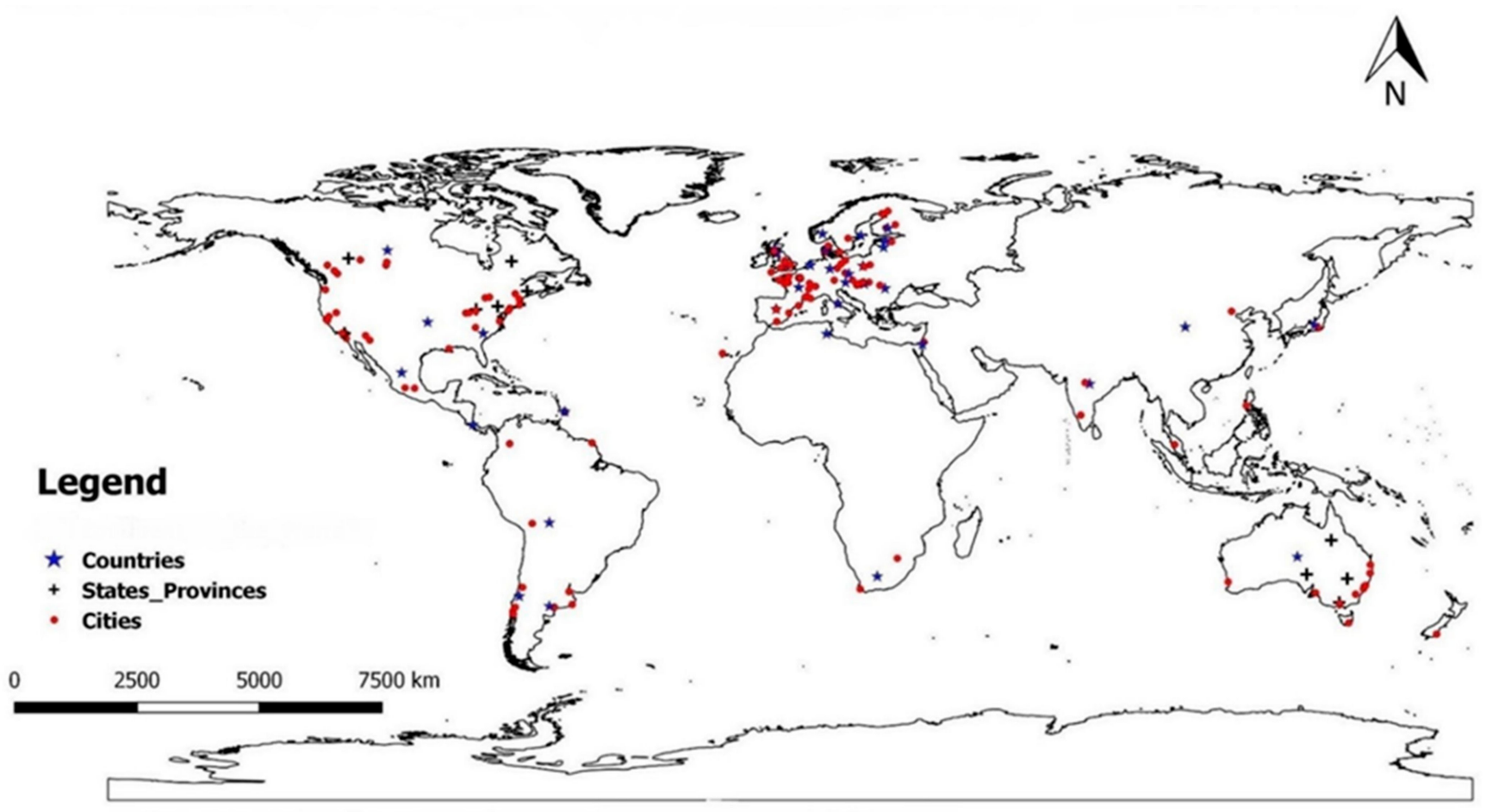

Figure 2. Distribution of research studies on urban bird traits across the world. Studies carried out at state or province level included multiple cities which were not specified in the publication.

\subsection{Ecological Traits}

\subsubsection{Bird Diversity and Abundance}

An overall decrease in diversity from rural to urban areas [25-27] as well as an increase in abundance of only a small subset of species are some of the most important ecological effects of urbanization on birds. One study observed a decreased overall abundance of birds in urban areas [28]. Species richness also shows a decreasing trend with an increase in urbanization, a pattern observed globally $[29,30]$. A study encompassing several cities in Europe observed that urban bird communities also showed lower evolutionary distinctiveness than rural communities [31]. A global review observed that, despite the loss of forest dependent or native species in urban areas, the functional diversity remained the same [32].

The species richness and density of seasonally migrating species also reduces with an increase in built infrastructure [33,34]. Many birds, such as Eurasian blackbird and house sparrow, show a loss in migratory behavior, as there are enough food resources available in urban areas to support them through the winter months. Such a trend may eventually lead to reduced richness in urban areas [35]. Birds with specific dietary requirements may also avoid migrating to cities because of a lack of adequate food resources. For example, insectivorous birds might find difficulty in finding insects in cities, thus reducing their urban population $[35,36]$. Studies also speculate the indirect effects of urbanization on resident vs. migrant bird dynamics. Resident species may occupy good quality nesting sites in cites before migrants arrive, thus driving migrants away from urban areas by competitive exclusion [37].

\subsubsection{Generalism-Specialism}

Specialist species are more likely to be negatively affected by change than generalists [38-40]. Devictor et al. [41] found that generalists, which use multiple habitats in the landscape matrix, are less affected by habitat fragmentation than specialists, which 
are dependent on one or a few habitat types. Generalists should benefit from disturbed landscapes, as there will be reduction in competition from specialists, who do well in stable environments and, hence, will be negatively affected by a degradation in landscape [42,43]. Generalist species usually have large niche breadths, lay multiple clutches, and have broad diets, which makes them more successful in cities [39]. This indicates that, to understand whether a bird can cope with urbanization, we need to consider the effects of multiple traits together.

Whether a species is a generalist or a specialist is largely due to the ability of these birds to adapt to feeding and nesting preferences, as described further below.

\subsubsection{Diet Breadth}

Diet breadth is one of the most important traits affected by urbanization [44,45]. Bird species that feed on fruits and grains tend to increase in numbers in urbanized areas as compared to insectivorous species $[37,46,47]$. This might be because cities have a substantial proportion of fruiting trees [48]. Similarly, a review on urban raptors suggested that urban areas are typically inhabited by raptors that are feeding on forest dwelling birds, due to a prevalence of large trees in cities, but open-area raptors feeding on grassland species do not generally inhabit urban areas [49]. Raptors feeding on rodents and scavenging raptors also show similar foraging, depending on the availability of suitable prey or carrion [50-52].

In many countries, there is a culture of putting out bird feeders, supplementing bird diets with seeds, nuts, and grains [53]. Granivorous birds benefit from this and, hence, do well in urbanized areas [27,37]. Callaghan et al. [39] observe that insectivorous and granivorous birds avoid urban areas, a phenomenon that requires further investigation in order to assess whether it is specific to countries where feeding birds is not a popular activity.

Kark et al. [44] report that, in downtown areas, most of the birds were omnivores, especially in temperate countries. Similarly, urban bird composition in Santiago, Chile, predominantly consisted of omnivorous and granivorous species [47]. Omnivorous species, like Eurasian blackbird, great tit (Parus major), and house sparrow, are commonly studied in urban avian ecology research (Figure 3). Again, omnivore birds are likely to feed on food scraps, discarded food items and, thus, seem to be possibly making use of the food resources that are discarded by humans. Apart from food preferences, urbanization can negatively affect birds exhibiting solitary feeding behavior [39]. Many birds show subtle changes in foraging behavior in order to adjust to the novel foraging sites. Ground foraging and insectivorous birds forage differentially in suburban remnant patches vs. continuous vegetation [54].

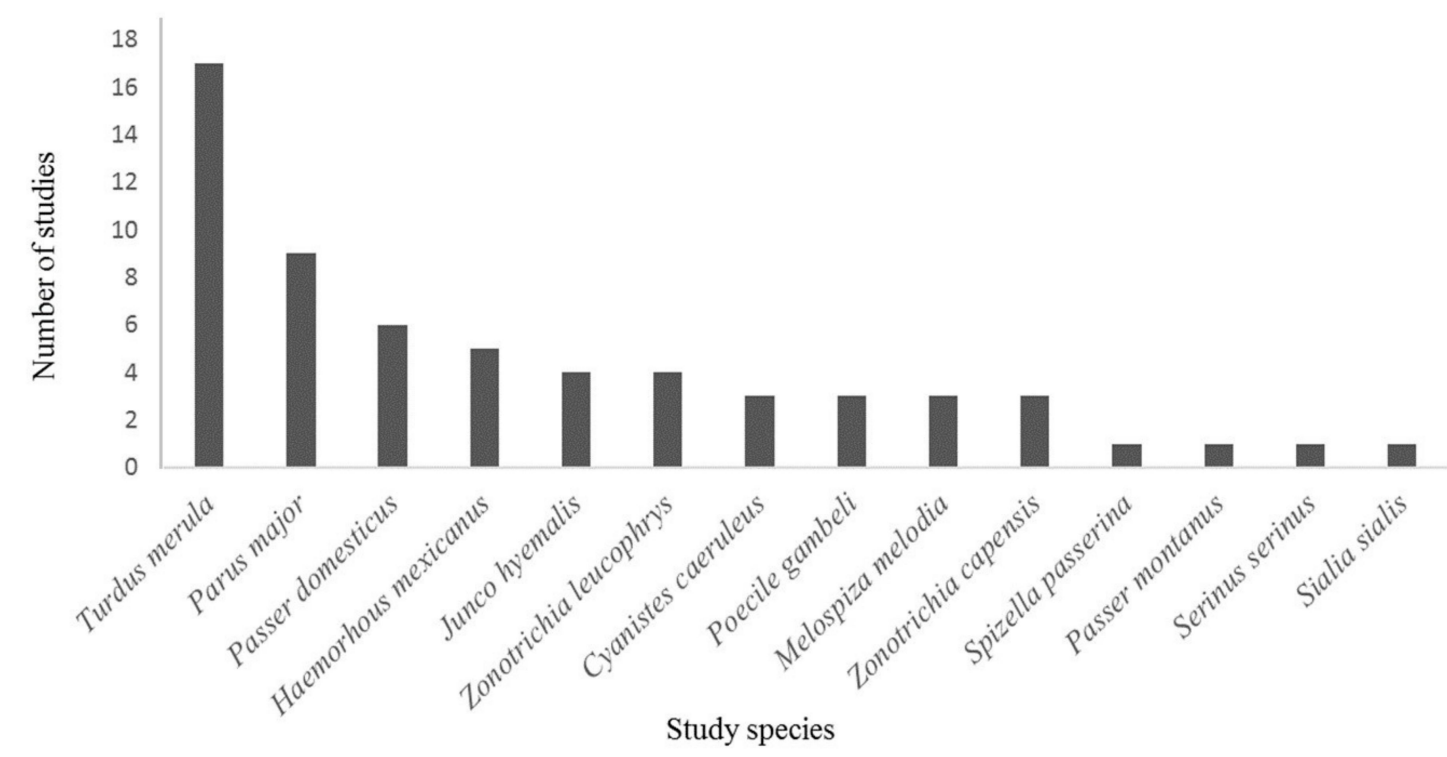

Figure 3. Most commonly studied bird species for urbanization induced trait changes. 


\subsubsection{Nesting Sites}

The utilization of nesting sites is an important factor determining the success of bird species [45]. One of the most consistent effects of urbanization is on ground-nesting birds, whose abundance consistently decreased across most of the studies [16,55]. Small sized ground nesters are most impacted by urbanization in Australia [56]. Birds that nest on high trees and in tree cavities have a better chance of survival in cities [37,57]. Studies speculate that urbanization does not necessarily increase the availability of cavity nesting sites. However, cavity nesters might be less prone to predation, because of their nesting habit, hence surviving better in cities [37]. Alternatively, cavity nesting birds might be using artificial nesting sites, such as nest boxes provided in cities. Cities with good tree cover will benefit birds that nest on trees, as there will not be a scarcity of nesting sites.

Birds that are more adaptable and use a variety of nesting strategies like making use of man-made structures, are more likely to do better in urban areas as compared to birds with specialized nesting preferences [58-60]. Adaptive nesting strategy also ensures better productivity, as is seen in the urban peregrine Falcon (Falco peregrinus), as many artificial structures provide better protection against predators or the elements [61]. Consequently, species that are adapted to urban conditions show higher abundance in urbanized areas $[8,59,62]$. Other birds, such as open-cup nesters, which require trees and shrubs to support their nests, are negatively associated with urbanized areas [59].

\subsection{Life History Traits}

Life history traits, such as clutch size and brood success, have a considerable positive impact on bird populations in urban areas [37]. Many urban species show an increase in the clutch size and brood size [63]. The increase in number of eggs and chicks helps these birds to overcome the losses that occurred during predation or the effects of urbanization such as mortality caused due to collision with cars or windows [37,61]. Urban birds tend to lay eggs earlier than their rural counterparts [64-68]. This might be because of the improved resource availability in cities. There are exceptions; Chamberlain et al. [69] found that, even though results vary from species to species, most urban bird populations are characterized by slightly greater annual productivity and lower nestling weight. However, certain species do not show such a pattern. For example, Marini et al. [70] find that clutch size does not differ in mountain chickadees (Poecile gambeli) as one moves along the urban-rural gradient in North America. Similarly, in magpies (Pica pica), a European species, the clutch size does not vary as one moves across the rural to urban gradient [71]. Brood size and nestlings per nesting attempt did not show a consistent pattern of differences between urban and non-urban areas [69]. Some raptor species also fledged fewer offspring in urban areas when there was a lack of prey or excessive human disturbance [68].

\subsection{Physiological Traits}

\subsubsection{Body Mass, Size, and Plumage Coloration}

Birds may produce large broods in urban areas, but the condition (average body size, morphological features) of offspring is poor, because there is a high chance of survival, even for the low-quality offspring [72,73]. The change in diet preferences might be associated with higher survival rates, but poor body condition. Birds have ample resources available throughout the year in the city, which is perhaps the reason they do not accumulate more body fat. Another possible reason is that temperatures in cities are higher due to urban heat island effects; hence, birds have smaller sizes: as theory predicts that as temperatures drop, body size increases [73]. Adverse ecological effects may also constrain the body size or condition of offspring [73]. Nestlings in urban habitats are fed less amount of food, or lower quality food, and they reach a lower body mass [74,75]. However, the urban area-smaller mass relation is not observed in all urban birds. A study on silver gulls (Larus novaehollandiae) in Tasmania found that adult male gulls in urban areas had greater body mass than adult male gulls in rural areas [76]. Perhaps omnivorous species show an opposite trend in terms of body mass due to the consumption of a wide variety of foods. 
Liker et al. [75] found that house sparrows were larger in rural areas as compared to urbanized areas. Sparrows in the Budapest city center were more than $5 \%$ lighter than sparrows at the least urbanized locations, and the leanness of urban birds was detectable, even when they compared differently urbanized habitats with similar utilization $[75,77]$.

Although the literature on body size and mass of urban birds is comprehensive, research is only now emerging on changes in plumage coloration in urban birds. A recent study across three cities in Argentina showed that the amount of built area negatively affected the color diversity of bird communities. Hence, the bird community in the city was predominantly composed of grey colored species [78]. Urbanization selects for birds with similar colors, primarily those matching the surrounding habitat. Because plumage coloration is an important trait, not only for the reproductive success of birds, but also as a camouflage to avoid detection, it is important to be studied on a larger spatial scale.

\subsubsection{Brain Size}

Birds and mammals with relatively larger brain size may be associated with the ability to invade novel habitats $[79,80]$. Callaghan et al. [39] hypothesize that birds with large brain size might be favored in cities and, hence, such birds should be successful in urban environments. Theory predicts that larger brains might be advantageous to individuals in dealing with altered environments and it might help in innovative behavior and learning [81]. Larger brain size implies that individuals might be more able to explore novel environments and food resources, helping such birds adapt to city life [5]. However, experimental studies suggest that there is a lot of variation in brain size and success in urban environments $[82,83]$. More work is required in order to definitively declare whether brain size is actually related to success in urban environments.

\subsubsection{Stress Response Physiology}

Urban birds are exposed to a variety of stressors, like traffic noise [84,85], artificial light pollution [86,87], uneven food distribution, and chemical pollution [85,88]. Stress response to such disturbances is indicated by the level of plasma corticosterone hormone (CORT) secretion [24,84,89-91]. Many studies have revealed changes in the baseline and induced corticosterone levels in birds in response to urban stresses [85,88-90]. The Eurasian blackbird female shows an increased corticosterone secretion in response to artificial light exposure [86], even though Partecke et al. [88] had observed an overall decrease in corticosterone secretion in urban blackbirds. Urban birds also show reduced corticosterone secretion in noisy environments when compared to rural populations, as is displayed by song sparrows (Melospiza melodia) [84] and house wrens (Troglodytes aedon) [85]. Reduced corticosterone in urban birds is associated with low protein diets [85]. The decrease in CORT secretion in species that have colonized urban areas for a long time could be due to habituation to these stressors $[84,86,89]$. When male song sparrows from different parts of city were compared for CORT levels, they did not show any difference, which further indicates that these urban song sparrows might be adapted to urban stressors [84]. Bonier [24] reviewed the various endocrine trait changes in urban birds and found no consistent pattern in stress hormone change in all urban species. Even within the populations, the differences fluctuated according to the age and life history stage.

Elevated levels of baseline corticosterone may have a considerable effect on other behavioral and physiological functions. Brain Arginine Vasotocin immunoreactivity, which is associated with various functions, like territoriality and social behavior, differs in response to changed plasma corticosterone in urban curve-billed thrashers (Toxostoma curvirostre) [92].

\subsubsection{Reproductive Physiology}

Living in urban areas influences reproduction in birds [24,93-96]. A global analysis of passerine species found that sexually dichromatic species were less likely to occur in urban areas [97]. 
Urban populations of Abert's towhees (Melozone aberti) are found to have greater plasma luteinizing hormone (hereafter plasma LH) than rural populations [67]. This leads to urban birds developing gonads earlier, starting breeding earlier, and having a prolonged breeding season than rural birds $[64,66,67,98-100]$. Having a prolonged breeding season might help in the production of more broods and, thus, might be an important trait to have in urban areas to successfully colonize them. Such earlier gonadal development is also prominent in resident rather than migratory birds, as observed in the males of urban Eurasian blackbirds [101] and dark-eyed junkos (Junco hyemalis) [101].

Partecke et al. [64] suggest phenotypic plasticity in response to several new conditions, like artificial lights, in urban areas to be the primary reason for this change. Birds living in temperate regions are especially dependent on day length and duration of natural light for their reproductive development $[95,98,99]$. The presence of artificial light in the city habitat plays a major role in the earlier growth of gonads in male birds [66,87,98,99,102,103]. However, low levels of artificial light inhibit the secretion of plasma LH in male western scrub jays (Aphelocoma californica) [91,95]. Apart from artificial light, differential food availability could also affect the pattern of plasma LH physiology $[69,91]$.

Factors, like the vegetation structure, replacement of native plants by exotic species, habitat fragmentation, predatory pressure, and food availability, influence the life history traits of urban birds $[69,104]$. The reason for lower clutch size in urban compared nonurban areas could be because of lower availability of high quality or specialized food in urban areas, especially during chick development [105]. Such deficiency in good quality food could also lead to increased competition between conspecifics during breeding season, affecting clutch size [69].

Such changes in reproductive physiology could affect life history traits, like fitness levels and nesting success of urban birds [98,99]. A prolonged breeding season could also be favored by urban birds, leading to fewer birds migrating for breeding [64,101].

\subsubsection{Immune and Inflammatory Responses, Oxidative Stress Response}

Physiological responses to various stressors in cities contribute to oxidative stress in urban birds $[106,107]$. Increased oxidative stress exposes birds to different types of diseases and organ degeneration [107]. A comparative study of blood and liver transcriptomes for these stress responses revealed that most of the genes for this stress response were expressed in a higher amount in urban birds [108]. An increase in blood antioxidant levels helps urban birds to tolerate such stress [106]. Successful urban colonizers use also genetic and epigenetic mechanisms, DNA methylation, and histone changes to cope with oxidative stress [107]. Urban Eurasian blackbirds developed lower oxidative stress when compared to rural populations, indicating an adaptation to high stress levels [109].

Physiological traits also closely influence behavioral traits: hormone secretion is associated with reproductive behavior, and brain size with innovation.

\subsection{Behavioral Traits}

\subsubsection{Song Structure}

One of the major characteristics of urban areas is the increase in low frequency noise levels, such as from traffic $[110,111]$. Birds in urban areas are impacted by noise in the low frequency range, as it carries over longer distances [111,112]. Low frequency anthropogenic noise tends to mask bird songs, which leads to poor song transmission, and, ultimately, poor reproductive success. Perhaps one of the most widely documented phenomena in behavioral trait changes in birds in response to urbanization is the modification of song and call structure to avoid such masking (Figure 4).

There are thought to be two mechanisms by which birds alter their song structure. One school of thought suggests that birds sing at higher frequencies in areas with high anthropogenic noise levels, as shown by studies on several species of song birds across different continents (e.g., [113-117]). In fact, high frequency songs are one of the selective forces for species to occupy urban habitats [118]. However, this mechanism might not 
always be effective for reproductive success [119-122]. White-crowned sparrow (Zonotrichia leucophrys) change song frequency and bandwidth, which leads to a reduction of vocal performance, which is deleterious for mate attraction and territory defense [120,122].

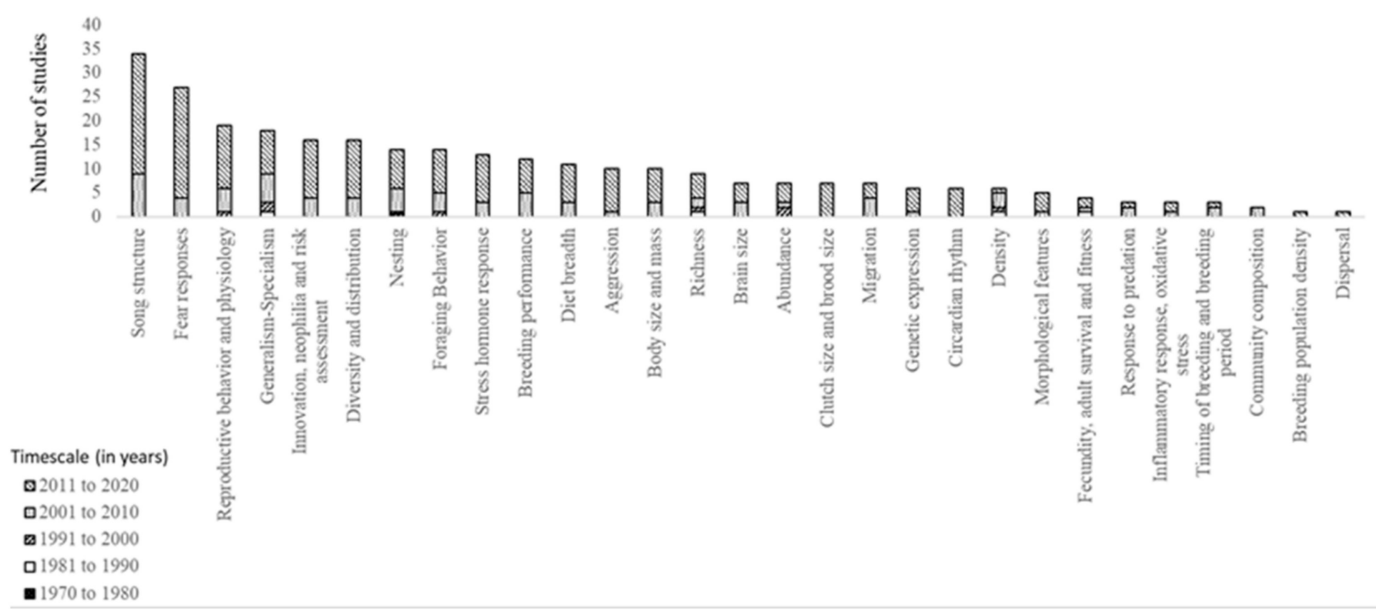

Figure 4. Proportion of studies in each decade from 1970 to 2020 on different trait changes due to urbanization.

Some birds also increase the amplitude of their songs, a phenomenon called "Lombard effect", in order to be heard above the city noises [111,123-126]. Great tits and Eurasian blackbirds are classic examples exhibiting this phenomenon [111]. Changes in bandwidth, trill rate, number of song syllables, and time spent singing have been documented in some birds, for effective song transmission [121,122,127-129]. Urban European robins (Erithacus rubecula) sing nocturnally in order to avoid song masking [35,110]. The alarm call structure is also modified due to masking. Urban silvereyes (Zosterops lateralis) had lower average, maximum, and minimum frequencies than rural birds [130]. Silvereyes also showed decreased syllable rate in Australia [131].

Apart from traffic noise, reflective structures, vegetation density, ambient temperature, and temporal changes in noise levels due to human activities also affect song communication in birds [132,133]. Male house finches (Haemorhous mexicanus) in an urban park in California sing at higher frequencies in areas with higher pedestrian traffic [134]. In the case of the great tit, this phenomenon is attributed to either large scale evolutionary or ontogenetic shift or a local scale song learning from neighboring males [112,113]. Morphological changes, like change in bill structure, due to differential food type in cities, could also change song structure [135].

Urban noise and artificial light levels affect the dawn chorus of urban bird populations $[136,137]$. Males of four out of five songbird species residing near street lights started singing earlier in the day. This increased their extra pair copulation success, but led to females selecting unsuitable mates [138]. Other studies found that more than artificial light, anthropogenic noise is responsible for temporal shift in the dawn chorus of the study species $[117,136,137]$.

\subsubsection{Boldness and Tolerance to Human Presence}

Urban habitats have a constant presence of humans and vehicles, altered refuge patches, and differential predator composition [139-144]. Flight initiation distance (FID) is a standard measure for estimating the boldness and tolerance of birds to potential threats in urban areas [23]. Urban birds are observed to be bolder and more tolerant of human and vehicular approach, as they exhibit shorter FIDs [145-152].

A shorter FID reduces the cost associated with flight, and it can help birds exploit novel food sources. Several species of gulls have shown shorter FID in the proximity of human food sources [153-155]. In a study on 39 urbanized species of birds in Europe, urban birds had shorter FIDs than rural counterparts. [156]. This study also showed that the urban 
bird community had a larger variance in FID when compared to rural bird communities, but this variance decreased with increase in time since urbanization. This means that most of the birds adapted to the threats in urban areas as the time since colonization increased.

Along with FID, urban birds have also adapted to the predation threat of feral animals, like cats and dogs. Urban Eurasian coots (Fulica atra) portrayed the same amount of vigilance in the presence of domestic dogs as their natural predators [139].

Behavioral plasticity, which is the inherent ability of an organism to change in response to external stimuli, is one of the main characteristics exhibited by birds who are capable of changing their fear responses. This is thought to be an important adaptation to possess in urban areas. [157-159]. However, it has been argued that habituation induced change is not the reason for the higher tolerance of humans in urban areas. Those individuals who already had a bold personality in their natural habitat were able to colonize urban areas, while others were unsuccessful [82].

\subsubsection{Neophobic and Innovative Behavior}

Urban areas provide novel types of food resources in the form of artificial feeding or garbage dumps [153,160-162]. Novel urban food sources also come with new types of risks in the form of feral cats and dogs [160,163-165]. Not all native birds have the ability to exploit such sources of food-it seems that bird species with innovative capability and bold personality have an increased capacity to thrive [152,166-168]. Several species of gulls exhibit a great ability to exploit human provided food, for example, by adjusting their foraging time according to peak human activity timing, like school breaks or waste center opening time [169]. Not just foraging innovation, but certain urban species, like Indian house crows (Corvus splendens), also show innovative nesting behavior after nesting failure during breeding season [170].

Successful urban colonization requires a balance between neophilia and neophobia [162]. Urban great tits are more tolerant towards a novel object that is placed near their feeders than rural individuals [165]. However, two different studies on house sparrows in Hungary and mountain chikadees in Reno, USA indicated no reduction in object neophobia in urban populations [171,172]. Griffin et al. [162], in a review, suggested that neophilia/neophobia and boldness might be species specific. Corvid species were more neophobic towards novel objects than non-corvid species [173].

Exposure to pollutants and inferior quality food during chick development might also affect the ability to exploit novel food sources as well as learning from parents and conspecifics [162,167]. Research pin pointing the factors influencing the ability to exploit novel urban resources is required.

The ability to innovate different foraging techniques is crucial for successful urban colonization by birds $[160,168,174]$. The rate of innovation seems to be stronger during early invasion of novel urban areas [5]. The rate of innovativeness also seems to predict the risk-taking ability of the species [168]. The rate of innovation has also been linked to brain size in some urban birds, which also assists in successful urban colonization [175]. Innovative foraging also leads to changes in dominance hierarchy, behavioral strategies that are based on human movement, and introduces new types of competitions [176].

\subsubsection{Aggression}

Aggressive behavior can be displayed towards competitors [176-179], can be food related [180], due to exposure to chemical pollutants [181], or during nest defense [182]. Urban great tits were more aggressive towards competitors, but they exhibited inconsistent reaction towards a simulated competition when compared to their rural counterparts [179].

Urban great tits also showed greater distress behavior when threatened [183]. In another study on northern mockingbird (Mimus polyglottos), urban birds that were exposed to higher amounts of lead were more aggressive towards simulated competition [181]. In Eurasian coot populations residing in the same urban area, older and more established populations were consistently more territorially aggressive than recently colonized popu- 
lation [184]. Urban sparrowhawks (Accipiter nisus) showed more aggressive nest defense than rural sparrowhawks [182]. These changes might not be just behavioral adaptations, but a consequence of micro-evolution over the years in these birds causing changes in the behavior. However, differences in territorial aggression in urban birds appears to be species and situation specific. The species that show increased aggressive behavior in urban areas also generally exhibit bolder personality $[155,176]$.

\subsection{Genetic Traits}

Although phenotypic trait changes in birds in response to urbanization have been extensively studied, solid evidence for genetic basis for such phenotypes is limited. Studies have focused on finding out the genetic modifications behind observed physiological trait changes like inflammatory and oxidative stress response, morphological trait changes, like change in wing structure, behavioral changes, like risk assessment, migration and urban invasion by certain functional groups [107]. The urban populations of great tits in Europe had elevated gene expression for inflammatory, oxidative stress, and detoxification responses [185]. Similar results were obtained for urban blue tits (Parus caeruleus) [186].

Urban Eurasian blackbirds have undergone genetic divergence at a locus coding for risk avoidance [187]. Human induced changes in habitat, along with various stressors, like the presence of novel predators, traffic noise, and pollutants, have led to accelerated changes in genotype in urban populations when compared to rural populations, with the potential to create genetic divergence between urban and non-urban populations [185]. However, an attempt to study the differences in overall genetic composition of Eurasian blackbirds yielded negative results [188]. This suggests that genetic differences between urban and rural populations have only occurred in selected genes, based on adaptive requirements. Urban blackbirds diverged from their rural populations at a single loci coding for risk avoidance [187]. However, there is still little evidence for urbanizationinduced micro-evolution.

\section{Discussion}

Some bird traits are beneficial for their survival in cities, while others could be harmful. This review demonstrates that the impact of urbanization on birds is immense: and yet, our understanding of it is still poor. It is evident that studying one trait might not give a complete picture of how urbanization might affect birds or populations, but looking at a combination of traits would provide more insights.

Behavioral trait changes are dependent on plasticity, individual personalities of the bird populations, and, at least for a few species, the development of separate cognitive skills that are specific to urban needs [22,170]. In particular, as our review demonstrates, behavioral trait changes in urban birds are often a combination of two or more trait changes. Such correlated changes create behavioral syndromes in urban birds [171]. An example of such behavioral syndromes is the occurrence of increased aggression in birds with bolder personalities [176].

The consequences of trait change have not yet been studied in detail, and they require attention. Urban birds could incur energetic and reproductive costs due to changed corticosterone levels or increased aggression in urban areas. The ability to establish a successful breeding population in novel environments also depends on the population size and selection pressure [22]. Earlier and prolonged breeding seasons could have negative effects on reproductive health of urban birds, especially females. Therefore, even though, in the short term, birds might be adapting to urbanization by producing more broods and laying more eggs, we need to understand whether these birds will be successful at surviving in cities in the long term. Additionally, it is important to understand the reasons behind some birds showing a reduction in clutch and brood size in urban areas. Long term data collection is needed for monitoring the population of birds inhabiting the cities. Popular citizen science initiatives can help to answer some of these questions. 
In the context of physiological and morphological trait changes, the literature suggests changes in stress hormone levels and reproductive hormone levels. The reason for the lack of consistent pattern in the differences in hormone levels in urban and non-urban populations could be due to the selection of physiologically plastic species in urban areas, which affects the life-history traits and ultimate density of the populations. This could mean potential extinction of species that are currently residing in urban areas, but are not able to adjust their physiology to the novel environment [24]. However, the effect of such differences in hormone levels on the overall fitness of the bird species that are successful in changing their endocrine traits has not yet been investigated in detail.

Trait changes in response to urbanization have the potential for creating genetic divergence between urban and rural populations of a species. The most important trait change contributing to genetic divergence is the change in reproductive behavior. A combination of different traits, like singing behavior, timing of reproduction, and nesting success, play a role in the reproductive pattern of birds. Urban areas modify these traits. Song birds possess high phenotypic plasticity and they have changed song structure in response to urban noise. Trait changes, coupled with isolation due to habitat fragmentation further leads to disconnect between urban and rural populations, leading to differential trait development in both populations. There is already evidence to suggest changes in genetic makeup at certain loci in urban and rural populations. Geographical isolation, coupled with high phenotypic plasticity, has a potential for further genetic divergence in urban birds. Large scale spatial and temporal studies, investigating such microevolution due to urbanization, could help in predicting the course of genetic divergence of urban bird populations in the future. Studying such urbanization induced genetic trait changes could help not only in conserving biodiversity in cities, but could also help to answer some of the basic questions in evolutionary ecology and also help in conserving the ecosystem services in cities [185].

There is a large gap in our knowledge regarding the effects of urbanization on birds in tropics, despite the fact that tropics support many more bird species and they are growing rapidly in terms of urbanization [55]. Future research in this area could also differentiate between introduced species and native species, in order to understand whether the traits discussed in this review contribute to the success of introduced species.

A lack of information regarding how urbanization will affect avifauna in urban tropics can be a major impeding factor while designing conservation strategies to protect the biodiversity in these ever-growing cities. Moreover, a study on southeast Asian cities found that, the wealthier the cities get, the richer they become in terms of urban greenspaces and natural aesthetics [189]. This could lead to potential habitat generation in growing cities, further affecting the bird traits.

Studies have started to emerge on the effect of urbanization on the traits of diurnal and nocturnal raptors in the last decade. Studies on urban raptors mainly focus on reproductive success, foraging pattern, and aggression in urban areas. Studies on top predatory bird species are essential while making management decisions, as these top predators might be responsible for keeping invasive faunal populations in check. For example, an increase in rodent populations on islands has led to the extinction of several island dwelling birds and other fauna [190]. Similar effects might affect bird populations in urban areas if proper management decisions are not taken at an appropriate time. Further, certain species are poorly represented in the research. Most of the studies that focus on species specific trait changes focus only on a few common species, such as great tits, Eurasian blackbirds, and house sparrows. Behavioral and physiological studies carried out on a couple of species might skew the literature in concluding effects of urbanization, either positive or negative and making generalizations. Caution should be taken that there is a lot of inter-species and intra-species variation and we need more studies looking at a variety of species and a combination of traits. For example, gulls seem to show extraordinary innovative ability around humans when compared to other urban birds. There is further scope to generate 
species specific databases in order to understand the effects of urbanization on diverse bird species and communities.

Urban areas provide a unique habitat in which to study community dynamics of birds. For example, in urban parks where there is a surge in activity during weekends, community composition of birds in these parks might be affected [78]. This could be very important, as, even though these are areas with good green cover, they might not be suitable nesting sites as park visitors might cause disturbance to nesting birds and might lead to abandoning the nest. On the other hand, these areas might be good areas to forage for fruits, seeds, and insects during the weekdays. An interesting hypothesis could be tested, looking at nesting success in the parks and outside the parks to actually see the effects of disturbance on bird communities and individual species.

\section{Conclusions}

The most significant trait changes that we identify have implications for urban avian diversity conservation, and they can be of use to park managers, citizen science groups, and urban planners. Omnivorous and cavity nesters have a better success in urban environments when compared to insectivores and ground nesting birds. Urban planners and park managers can maintain small patches of land that are enclosed to protect against common urban predators. such as feral dogs, cats, and rodents, in order to provide ground nesting birds that are especially endangered with refugia for roosting and nesting. Another important suggestion to bird enthusiasts and urban planners would be to include a variety of food items in bird feeders, as this might help birds with different diets to meet their nutrition requirements. Studies have shown that frugivores and granivores seem to do well in cities, as these birds feed on the seeds that are provided by people in bird feed. There has been evidence that, when artificial food is provided birds expand their ranges, thus having a positive effect on bird populations [78]. If dried insects and nuts are included in the food, it might help insectivorous birds in the city. If bigger cavity nests are provided for birds, like owls and other larger species, then these species might bounce back in good numbers in the cities. Additionally, maintaining patches of native vegetation in urban habitats might be a great solution for supporting not only the bird species, but also insects and small mammal communities that can serve as a prey base to the birds. Along with patches of native vegetation, it is also crucial to conserve the local water bodies in cities, as these act as refuges for several migratory birds and local waders [46,191]. In the Mediterranean, it was observed that the natural waterbodies were key habitat for several species of owls [192]. Hence, the health of the lakes, ponds, and rivers is crucial for the survival of many urban species.

Species specific studies and detailed knowledge of local bird populations can greatly help in effective management measures, as we find substantial, documented variation in how birds of specific species respond to the pressures of urbanization. We hope for the long- term monitoring of bird populations while using a combination of detailed scientific research and citizen science initiatives, as demonstrated in the papers reviewed here, can help to bridge gaps in knowledge and benefit the future survival of a diverse range of birds in urban environments. To conclude, using a trait-based approach will be useful for understanding the impacts of urbanization on bird species. Understanding the role of traits with an understanding of urban changes will be most useful. In particular, we stress the need for further research on the traits that influence bird survival in tropical cities, as well as on individual species. A meta-analyses kind of an approach encompassing multiple traits together was out of scope for this study, as enough information on each trait is still not available. Some traits have enough literature, others have hardly a couple of studies. However, this review could act as a baseline for further research on urban wildlife and its ecology.

Supplementary Materials: The following are available online at https:/ / www.mdpi.com/2073-445 X/10/2/92/s1, Figure S1: List of journals which published the $(>1)$ articles reviewed in the current study; Table S1: All traits considered for selecting the literature were distributed under five broad 
trait groups. In total, 32 sub-traits were considered for this study. The broad description of these sub-traits is given below; Table S2: List of publications reviewed for this study.

Author Contributions: S.P.: Conceptualization, Methodology, Data Curation, Analysis, WritingOriginal Draft Preparation, Reviewing and Editing. R.J.: Conceptualization, Methodology, Data Curation, Analysis, Writing-Original Draft Preparation, Reviewing and Editing. K.R.S.: Conceptualization, Supervision, Writing-Reviewing and Editing. H.N.: Conceptualization, Methodology, Supervision, Writing-Original Draft Preparation, Reviewing and Editing, Project administration. All authors have read and agreed to the published version of the manuscript.

Funding: This research received no external funding.

Acknowledgments: The authors thank Azim Premji University, Bangalore for supporting this research. This research did not receive any specific grant from funding agencies in the public, commercial, or not-for-profit sectors.

Conflicts of Interest: The authors declare no conflict of interest.

\section{References}

1. McKinney, M.L. Urbanization, biodiversity and conservation. BioScience 2002, 52, 883-890. [CrossRef]

2. Kowarik, I. Novel urban ecosystems, biodiversity, and conservation. Environ. Pollut 2011, 159, 1974-1983. [CrossRef] [PubMed]

3. UNDESA. 2018 The Sustainable Development Goals Report; United Nations: New York, NY, USA, 2018; Available online: https:/ / www.un.org/development/desa/publications/the-sustainable-development-goals-report-2018.html (accessed on 20 June 2020).

4. Lepczyk, C.A.; Aronson, M.F.; Evans, K.L.; Goddard, M.A.; Lerman, S.B.; MacIvor, J.S. Biodiversity in the city: Fundamental questions for understanding the ecology of urban green spaces for biodiversity conservation. BioScience 2017, 67, 799-807. [CrossRef]

5. Sol, D.; Duncan, R.P.; Blackburn, T.M.; Cassey, P.; Lefebvre, L. Big brains, enhanced cognition, and response of birds to novel environments. Proc. Natl. Acad. Sci. USA 2005, 102, 5460-5465. [CrossRef] [PubMed]

6. Liu, Z.; He, C.; Wu, J. The relationship between habitat loss and fragmentation during urbanization: An empirical evaluation from 16 world cities. PLoS ONE 2016, 11, e0154613. [CrossRef] [PubMed]

7. Belaire, J.A.; Westphal, L.M.; Whelan, C.J.; Minor, E.S. Urban residents' perceptions of birds in the neighborhood: Biodiversity, cultural ecosystem services, and disservices. Condor 2015, 117, 192-202. [CrossRef]

8. Aronson, M.F.; la Sorte, F.A.; Nilon, C.H.; Katti, M.; Goddard, M.A.; Lepczyk, C.A.; Warren, P.S.; Williams, N.S.; Cilliers, S.; Clarkson, B.; et al. A global analysis of the impacts of urbanization on bird and plant diversity reveals key anthropogenic drivers. Proc. R. Soc. B Biol. Sci. 2014, 281, 20133330. [CrossRef]

9. Hensley, C.B.; Trisos, C.H.; Warren, P.S.; MacFarland, J.; Blumenshine, S.; Reece, J.; Katti, M. Effects of urbanization on native bird species in three southwestern US Cities. Front. Ecol. Evol. 2019, 7, 71. [CrossRef]

10. Whelan, C.J.; Wenny, D.G.; Marquis, R.J. Ecosystem services provided by birds. Ann. N. Y. Acad. Sci. 2008, 1134, 25-60. [CrossRef]

11. Sandström, U.G.; Angelstam, P.; Mikusiński, G. Ecological diversity of birds in relation to the structure of urban green space. Landsc. Urban Plan 2006, 77, 39-53. [CrossRef]

12. Goodness, J.; Andersson, E.; Anderson, P.M.; Elmqvist, T. Exploring the links between functional traits and cultural ecosystem services to enhance urban ecosystem management. Ecol. Indic. 2016, 70, 597-605. [CrossRef]

13. Heyman, E.; Gunnarsson, B.; Dovydavicius, L. Management of urban nature and its impact on bird ecosystem services. In Ecology and Conservation of Birds in Urban Environments; Murgui, E., Hedblom, M., Eds.; Springer: Cham, Switzerland, 2017; pp. 465-488.

14. Gil, D.; Brumm, H. Avian Urban Ecology, 1st ed.; Oxford University Press: Oxford, UK, 2014; pp. xiii-xv.

15. Kumar, N.; Gupta, U.; Malhotra, H.; Jhala, Y.V.; Qureshi, Q.; Gosler, A.G.; Sergio, F. The population density of an urban raptor is inextricably tied to human cultural practices. Proc. R. Soc. B Biol. Sci. 2019, 286, 20182932. [CrossRef] [PubMed]

16. Chace, J.F.; Walsh, J.J. Urban effects on native avifauna: A review. Landsc. Urban Plan 2006, 74, 46-69. [CrossRef]

17. Palacio, F.X. Urban exploiters have broader dietary niches than urban avoiders. Ibis 2019, 162, 42-49. [CrossRef]

18. Leveau, L.M. Bird traits in urban-rural gradients: How many functional groups are there? J. Ornithol. 2013, 154, 655-662. [CrossRef]

19. Lizée, M.H.; Mauffrey, J.F.; Tatoni, T.; Deschamps-Cottin, M. Monitoring urban environments on the basis of biological traits. Ecol. Indic. 2011, 11, 353-361. [CrossRef]

20. Rooney, T.P.; Wiegmann, S.M.; Rogers, D.A.; Waller, D.M. Biotic impoverishment and homogenization in unfragmented forest understory communities. Conserv. Biol. 2004, 18, 787-798. [CrossRef]

21. Shochat, E.; Lerman, S.; Fernández-Juricic, E. Birds in urban ecosystems: Population dynamics, community structure, biodiversity, and conservation. In Urban Ecosystem Ecology, 1st ed.; Aitkenhead-Peterson, J.A., Volder, A., Eds.; American Agronomy Society: Madison, WI, USA, 2010; pp. 75-86.

22. Sol, D.; González-Lagos, C.; Moreira, D.; Maspons, J.; Lapiedra, O. Urbanization tolerance and the loss of avian diversity. Ecol. Lett. 2014, 17, 942-950. [CrossRef] [PubMed] 
23. Blumstein, D.T. Attention, habituation, and antipredator behavior: Implications for urban birds. In Avian Urban Ecology; Diego, G., Henrik, B., Eds.; Oxford University Press: Oxford, UK, 2014; pp. 41-53.

24. Bonier, F. Hormones in the city: Endocrine ecology of urban birds. Horm. Behav. 2012, 61, 763-772. [CrossRef]

25. Rayner, L.; Ikin, K.; Evans, M.J.; Gibbons, P.; Lindenmayer, D.B.; Manning, A.D. Avifauna and urban encroachment in time and space. Divers. Distrib. 2015, 21, 428-440. [CrossRef]

26. Leveau, L.M.; Leveau, C.M.; Villegas, M.; Cursach, J.A.; Suazo, C.G. Bird communities along urbanization gradients: A comparative analysis among three neo-tropical cities. Ornitol. Neotrop. 2017, 28, 77-87.

27. la Sorte, F.A.; Lepczyk, C.A.; Aronson, M.F.J.; Goddard, M.A.; Hedblom, M.; Katti, M.; MacGregor-Fors, I. The phylogenetic and functional diversity of regional breeding bird assemblages is reduced and constricted through urbanization. Divers. Distrib. 2018, 24, 928-938. [CrossRef]

28. Saari, S.; Richter, S.; Higgins, M.; Oberhofer, M.; Jennings, A.; Faeth, S.H. Urbanization is not associated with increased abundance or decreased richness of terrestrial animals-dissecting the literature through meta-analysis. Urban Ecosyst. 2016, 19, 1251-1264. [CrossRef]

29. Ibáñez-Álamo, J.D.; Rubio, E.; Benedetti, Y.; Morelli, F. Global loss of avian evolutionary uniqueness in urban areas. Glob. Chang. Biol. 2017, 23, 2990-2998. [CrossRef] [PubMed]

30. Batáry, P.; Kurucz, K.; Suarez-Rubio, M.; Chamberlain, D.E. Non-linearities in bird responses across urbanization gradients: A meta-analysis. Glob. Chang. Biol. 2018, 24, 1046-1054. [CrossRef]

31. Morelli, F.; Benedetti, Y.; Ibáñez-Álamo, J.D.; Jokimäki, J.; Mänd, R.; Tryjanowski, P.; Møller, A.P. Evidence of evolutionary homogenization of bird communities in urban environments across Europe. Glob. Ecol. Biogeogr. 2016, 25, 1284-1293. [CrossRef]

32. Hagen, O.E.; Hagen, O.; Ibáñez-Álamo, J.D.; Petchey, O.L.; Evans, K.L. Impacts of urban areas and their characteristics on avian functional diversity. Front. Ecol. Evol. 2017, 5, 84. [CrossRef]

33. Shochat, E.; Warren, P.S.; Faeth, S.H.; McIntyre, N.E.; Hope, D. From patterns to emerging processes in mechanistic urban ecology. Trends Ecol. Evol. 2006, 21, 186-191. [CrossRef]

34. MacGregor-Fors, I.; Morales-Pérez, L.; Schondube, J.E. Migrating to the city: Responses of neo-tropical migrant bird communities to urbanization. Condor 2010, 112, 711-717. [CrossRef]

35. Leveau, L.M. Urbanization, environmental stabilization and temporal persistence of bird species: A view from Latin America. PeerJ 2018, 6, e6056. [CrossRef]

36. Faeth, S.H.; Bang, C.; Saari, S. Urban biodiversity: Patterns and mechanisms. Ann. N. Y. Acad. Sci. 2011, 1223, 69-81. [CrossRef] [PubMed]

37. Paton, G.D.; Shoffner, A.V.; Wilson, A.M.; Gagne, S.A. The traits that predict the magnitude and spatial scale of forest bird responses to urbanization intensity. PLoS ONE 2019, 14, e0220120. [CrossRef] [PubMed]

38. Julliard, R.; Jiguet, F.; Couvet, D. Common birds facing global changes: What makes a species at risk? Glob. Chang. Biol. 2004, 10, 148-154. [CrossRef]

39. Callaghan, C.T.; Major, R.E.; Wilshire, J.H.; Martin, J.M.; Kingsford, R.T.; Cornwell, W.K. Generalists are the most urban-tolerant of birds: A phylogenetically controlled analysis of ecological and life history traits using a novel continuous measure of bird responses to urbanization. Oikos 2019, 128, 845-858. [CrossRef]

40. Callaghan, C.T.; Benedetti, Y.; Wilshire, J.H.; Morelli, F. Avian trait specialization is negatively associated with urban tolerance. Oikos 2020, 129, 1541-1551. [CrossRef]

41. Devictor, V.; Julliard, R.; Couvet, D.; Lee, A.; Jiguet, F. Functional homogenization effect of urbanization on bird communities. Conserv. Biol. 2007, 21, 41-751. [CrossRef]

42. Futuyama, D.J.; Moreno, G. The evolution of ecological specialization. Annu. Rev. Ecol. Evol. S 1988, 19, 207-233. [CrossRef]

43. Kitahara, M.; Sei, K.; Fujii, K. Patterns in the structure of grassland butterfly communities along a gradient of human disturbance: Further analysis based on the generalist/specialist concept. Popul. Ecol. 2000, 42, 135-144. [CrossRef]

44. Kark, S.; Iwaniuk, A.; Schalimtzek, A.; Banker, E. Living in the city: Can anyone become an 'urban exploiter? J. Biogeogr. 2007, 34, 638-651. [CrossRef]

45. Evans, K.L.; Chamberlain, D.E.; Hatchwell, B.J.; Gregory, R.D.; Gaston, K.J. What makes an urban bird? Glob. Chang. Biol. 2011, 17, 1365-2486. [CrossRef]

46. Morelli, F.; Benedetti, Y.; Su, T.; Zhou, B.; Moravec, D.; Šímová, P.; Liang, W. Taxonomic diversity, functional diversity and evolutionary uniqueness in bird communities of Beijing's urban parks: Effects of land use and vegetation structure. Urban Urban Green. 2017, 23, 84-92. [CrossRef]

47. Gutiérrez-Tapia, P.; Azócar, M.I.; Castro, S.A. A citizen-based platform reveals the distribution of functional groups inside a large city from the Southern Hemisphere: E-Bird and the urban birds of Santiago (Central Chile). Rev. Chil. Hist. Nat. 2018, 91, 3. [CrossRef]

48. Lim, H.C.; Sodhi, N.S. Responses of avian guilds to urbanization in a tropical city. Landsc. Urban Plan 2004, 66, 199-215. [CrossRef]

49. Boal, C.W. Urban raptor communities: Why some raptors and not others occupy urban environments. In Urban Raptors; Boal, C.W., Dykstra, C.R., Eds.; Island Press: Washington, DC, USA, 2018; pp. 36-50.

50. Hindmarch, S.; Elliott, J.E. A specialist in the city: The diet of barn owls along a rural to urban gradient. Urban Ecosyst. 2015, 18, 477-488. [CrossRef] 
51. Rullman, S.; Marzluff, J.M. Raptor presence along an urban-wildland gradient: Influences of prey abundance and land cover. J. Raptor Res. 2014, 48, 257-272. [CrossRef]

52. Thomson, V.K.; Stevens, T.; Jones, D.; Huijbers, C. Carrion preference in Australian coastal raptors: Effects of Urbanisation on scavenging. Sunbird 2016, 46, 16.

53. Jones, D.N.; Reynolds, J.S. Feeding birds in our towns and cities: A global research opportunity. J. Avian Biol. 2008, 39, $265-271$. [CrossRef]

54. Hodgson, P.; French, K.; Major, R.E. Comparison of foraging behavior of small, urban-sensitive insectivores in continuous woodland and woodland remnants in a suburban landscape. Wildl. Res. 2006, 33, 591-603. [CrossRef]

55. Marzluff, J.M.; Bowman, R.; Donnelly, R. (Eds.) A historical perspective on urban bird research: Trends, terms, and approaches. In Avian Ecology and Conservation in an Urbanizing; World Springer: Boston, MA, USA, 2001; pp. 1-17.

56. Ikin, K.; Knight, E.; Lindenmayer, D.B.; Fischer, J.; Manning, A.D. Linking bird species traits to vegetation characteristics in a future urban development zone: Implications for urban planning. Urban Ecosyst. 2012, 15, 961-977. [CrossRef]

57. Croci, S.; Butet, A.; Clergeau, P. Does urbanization filter birds on the basis of their biological traits. Condor 2008, 110, 223-240. [CrossRef]

58. Reale, J.A.; Blair, R.B. Nesting success and life-history attributes of bird communities along an urbanization gradient. Urban Habitats 2005, 3, 1-24.

59. Máthé, O.; Batáry, P. Insectivorous and open-cup nester bird species suffer the most from urbanization. Bird Study 2015, 62, 78-86. [CrossRef]

60. Dykstra, C.R. City Lifestyles: Behavioral Ecology of Urban Raptors. In Urban Raptors; Boal, C.W., Dykstra, C.R., Eds.; Island Press: Washington, DC, USA, 2018; pp. 18-35.

61. Gahbauer, M.A.; Bird, D.M.; Clark, K.E.; French, T.; Brauning, D.W.; Mcmorris, F.A. Productivity, mortality, and management of urban peregrine falcons in northeastern North America. J. Wildl. Manag. 2015, 79, 10-19. [CrossRef]

62. Mason, C.F. Avian species richness and numbers in the built environment: Can new housing developments be good for birds? In Human Exploitation and Biodiversity Conservation; Hawksworth, D.L., Bull, A.T., Eds.; Springer: Dordrecht, The Netherlands, 2006; pp. 2365-2378.

63. Thornton, M.; Todd, I.; Roos, S. Breeding success and productivity of urban and rural Eurasian Sparrowhawks Accipiter nisus in Scotland. Écoscience 2017, 24, 115-126. [CrossRef]

64. Partecke, J.; Van't-Hof, T.; Gwinner, E. Differences in the timing of reproduction between urban and forest European blackbirds (Turdus merula): Result of phenotypic flexibility or genetic differences? Proc. R. Soc. B Biol. Sci. 2004, 271, 1995-2001. [CrossRef]

65. Atwell, J.W.; Cardoso, G.; Whittaker, D.J.; Price, T.D.; Ketterson, E.D. Hormonal, behavioral, and life-history traits exhibit correlated shifts in relation to population establishment in a novel environment. Am. Nat. 2014, 184, E147-E160. [CrossRef]

66. Zhang, S.; Chen, X.; Zhang, J.; Li, H. Differences in the reproductive hormone rhythm of Tree sparrows (Passer montanus) from urban and rural sites in Beijing: The effect of anthropogenic light sources. Gen. Comp. Endocrinol. 2014, 206, 24-29. [CrossRef]

67. Davies, S.; Behbahaninia, H.; Giraudeau, M.; Meddle, S.L.; Waites, K.; Deviche, P. Advanced seasonal reproductive development in a male urban bird is reflected in earlier plasma luteinizing hormone rise but not energetic status. Gen. Comp. Endocrinol. 2015, 224, 1-10. [CrossRef]

68. Kettel, E.F.; Gentle, L.K.; Quinn, J.L.; Yarnell, R.W. The breeding performance of raptors in urban landscapes: A review and meta-analysis. J. Ornithol. 2018, 159, 1-18. [CrossRef]

69. Chamberlain, D.E.; Cannon, A.R.; Toms, M.P.; Leech, D.I.; Hatchwell, B.J.; Gaston, K.J. Avian productivity in urban landscapes: A review and meta-analysis. Ibis 2009, 151,1-18. [CrossRef]

70. Marini, K.L.D.; Otter, K.A.; LaZerte, S.E.; Reudink, M.W. Urban environments are associated with earlier clutches and faster nestling feather growth compared to natural habitats. Urban Ecosyst. 2017, 20, 1291-1300. [CrossRef]

71. Antonov, A.; Atanasova, D. Small-scale differences in the breeding ecology of urban and rural magpies (Pica pica). Ornis Fennica 2003, 80, 21-30.

72. Shochat, E.; Lerman, S.B.; Katti, M.; Lewis, D.B. Linking optimal foraging behavior to bird community structure in an urban-desert landscape: Field experiments with artificial food patches. Am. Nat. 2004, 164, 232-243. [CrossRef] [PubMed]

73. Caizergues, A.E.; Grégoire, A.; Charmantier, A. Urban versus forest ecotypes are not explained by divergent reproductive selection. Proc. R. Soc. B Biol. Sci. 2018, 285, 20180261. [CrossRef]

74. Mennechez, G.; Clergeau, P. Effect of urbanization on habitat generalists: Starlings not so flexible? Acta Oecol. 2006, 30, 182-191. [CrossRef]

75. Liker, A.; Papp, Z.; Bókony, V.; Lendvai, A.Z. Lean birds in the city: Body size and condition of house sparrows along the urbanization gradient. J. Anim. Ecol. 2008, 77, 789-795. [CrossRef]

76. Auman, H.J.; Meathrel, C.E.; Richardson, A. Supersize me: Does anthropogenic food change the body condition of Silver Gulls? A comparison between urbanized and remote, non-urbanized areas. Waterbirds 2008, 31, 122-126. [CrossRef]

77. Bókony, V.; Seress, G.; Nagy, S.; Lendvai, A.Z.; Liker, A. Multiple indices of body condition reveal no negative effect of urbanization in adult house sparrows. Landsc. Urban Plan 2012, 104, 75-84. [CrossRef]

78. Leveau, L.M. Urbanization induces bird color homogenization. Landsc. Urban Plan 2019, 192, 103645. [CrossRef]

79. Sol, D.; Bacher, S.; Reader, S.M.; Lefebvre, L. Brain size predicts the success of mammal species introduced into novel environments. Am. Nat. 2008, 172, 63-71. [CrossRef] 
80. Maklakov, A.A.; Immler, S.; Gonzalez-Voyer, A.; Rönn, J.; Kolm, N. Brains and the city: Big-brained passerine birds succeed in urban environments. Biol. Lett. 2011, 7, 730-732. [CrossRef] [PubMed]

81. Carrete, M.; Tella, J.L. Inter-individual variability in fear of humans and relative brain size of the species are related to contemporary urban invasion in birds. PLoS ONE 2011, 6, e18859. [CrossRef] [PubMed]

82. Møller, A.P. Behavioural and ecological predictors of urbanization. In Avian Urban Ecology; Gil, D., Brumm, H., Eds.; Oxford University Press: Oxford, UK, 2014; pp. 54-68.

83. Møller, A.P.; Erritzøe, J. Brain size and urbanization in birds. Avian Res. 2015, 6, 8. [CrossRef]

84. Grunst, M.L.; Rotenberry, J.T.; Grunst, A.S. Variation in adrenocortical stress physiology and condition metrics within a heterogeneous urban environment in the Song sparrow (Melospiza melodia). J. Avian Biol. 2014, 45, 574-583. [CrossRef]

85. Davies, S.; Haddad, N.; Ouyang, J.Q. Stressful city sounds: Glucocorticoid responses to experimental traffic noise are environmentally dependent. Biol. Lett. 2017, 13, 20170276. [CrossRef] [PubMed]

86. Russ, A.; Reitemeier, S.; Weissmann, A.; Gottschalk, J.; Einspanier, A.; Klenke, R. Seasonal and urban effects on the endocrinology of a wild passerine. Ecol. Evol. 2015, 5, 5698-5710. [CrossRef]

87. Dominoni, D.M. The effects of light pollution on biological rhythms of birds: An integrated, mechanistic perspective. J. Ornithol. 2015, 156, 409-418. [CrossRef]

88. Partecke, J.; Schwabl, I.; Gwinner, E. Stress and the city: Urbanization and its effects on the stress physiology in European blackbirds. Ecology 2006, 87, 1945-1952. [CrossRef]

89. Fokidis, H.B.; Deviche, P. Plasma corticosterone of city and desert Curve-billed Thrashers, (Toxostoma curvirostre), in response to stress-related peptide administration. Comp. Biochem. Physiol. A Mol. Integr. Physiol. 2011, 159, 32-38. [CrossRef]

90. Zhang, S.; Lei, F.; Liu, S.; Li, D.; Chen, C.; Wang, P. Variation in baseline corticosterone levels of Tree sparrow (Passer montanus) populations along an urban gradient in Beijing, China. J. Ornithol. 2011, 152, 801-806. [CrossRef]

91. Davies, S.; Rodriguez, N.S.; Sweazea, K.L.; Deviche, P. The effect of acute stress and long-term corticosteroid administration on plasma metabolites in an urban and Desert songbird. Physiol. Biochem. Zool. 2013, 86, 47-60. [CrossRef] [PubMed]

92. Fokidis, H.B.; Deviche, P. Brain arginine vasotocin immunoreactivity differs between urban and desert curve-billed thrashers, (Toxostoma curvirostre): Relationships with territoriality and stress physiology. Brain Behav. Evol. 2012, 79, 84-97. [CrossRef] [PubMed]

93. Yeh, P.J.; Price, T.D. Adaptive phenotypic plasticity and the successful colonization of a novel environment. Am. Nat. 2004, 164, 531-542. [CrossRef] [PubMed]

94. Rodewald, A.D.; Shustack, D.P. Urban flight: Understanding individual and population-level responses of Nearctic-Neotropical migratory birds to urbanization. J. Anim. Ecol. 2008, 77, 83-91. [CrossRef] [PubMed]

95. Schoech, S.J.; Bowman, R.; Hahn, T.P.; Goymann, W.; Schwabl, I.; Bridge, E.S. The effects of low levels of light at night upon the endocrine physiology of Western scrub-jays (Aphelocoma californica). J. Exp. Zool. A Ecol. Integr. Physiol. 2013, 319, 527-538. [CrossRef] [PubMed]

96. Brown, L.M.; Graham, C.H. Demography, traits and vulnerability to urbanization: Can we make generalizations? J. Appl. Ecol. 2015, 52, 1455-1464. [CrossRef]

97. Iglesias-Carrasco, M.; Duchêne, D.A.; Head, M.L.; Møller, A.P.; Cain, K. Sex in the city: Sexual selection and urban colonization in passerines. Biol. Lett. 2019, 15, 20190257. [CrossRef]

98. Dominoni, D.M.; Quetting, M.; Partecke, J. Long-term effects of chronic light pollution on seasonal functions of European blackbirds (Turdus merula). PLoS ONE 2013, 8, e85069. [CrossRef]

99. Dominoni, D.M.; Quetting, M.; Partecke, J. Artificial light at night advances avian reproductive physiology. Proc. R. Soc. B Biol. Sci. 2013, 280, 20123017. [CrossRef]

100. Fudickar, A.M.; Greives, T.J.; Abolins-Abols, M.; Atwell, J.W.; Meddle, S.L.; Friis, G.; Stricker, C.A.; Ketterson, E.D. Mechanisms associated with an advance in the timing of seasonal reproduction in an urban songbird. Front. Ecol. Evol. 2017, 5, 85. [CrossRef]

101. Partecke, J.; Gwinner, E. Increased sedentariness in European blackbirds following urbanization: A consequence of local adaptation? Ecology 2007, 88, 882-890. [CrossRef] [PubMed]

102. Longcore, T. Sensory ecology: Night lights alter reproductive behavior of Blue tits. Curr. Biol. 2010, 20, R893-R895. [CrossRef] [PubMed]

103. Dominoni, D.M.; Goymann, W.; Helm, B.; Partecke, J. Urban-like night illumination reduces melatonin release in European blackbirds (Turdus merula): Implications of city life for biological time-keeping of songbirds. Front. Zool. 2013, 10, 60. [CrossRef] [PubMed]

104. Reynolds, S.J.; Ibáñez-Álamo, J.D.; Sumasgutner, P.; Mainwaring, M.C. Urbanization and nest building in birds: A review of threats and opportunities. J. Ornithol. 2019, 160, 841-860. [CrossRef]

105. Wawrzyniak, J.; Kaliński, A.; Glądalski, M.; Bańbura, M.; Markowski, M.; Skwarska, J.; Kaliński, P.; Cyżewska, I.; Bańbura, J. Long-term variation in laying date and clutch size of the Great tit (Parus major) in central Poland: A comparison between urban parkland and deciduous forest. Ardeola 2015, 62, 311-323. [CrossRef]

106. Møller, A.P. Successful city dwellers: A comparative study of the ecological characteristics of urban birds in the Western Palearctic. Oecologia 2009, 159, 849-858. [CrossRef] [PubMed]

107. Isaksson, C. Urbanization, oxidative stress and inflammation: A question of evolving, acclimatizing or coping with urban environmental stress. Funct. Ecol. 2015, 29, 913-923. [CrossRef] 
108. Watson, H.; Videvall, E.; Andersson, M.N.; Isaksson, C. Transcriptome analysis of a wild bird reveals physiological responses to the urban environment. Sci. Rep. 2017, 7, 44180. [CrossRef]

109. Costantini, D.; Greives, T.J.; Hau, M.; Partecke, J. Does urban life change blood oxidative status in birds? J. Exp. Biol. 2014, 217, 2994-2997. [CrossRef]

110. Fuller, R.A.; Warren, P.H.; Gaston, K.J. Daytime noise predicts nocturnal singing in urban robins. Biol. Lett. 2007, 3, 368-370. [CrossRef]

111. Nemeth, E.; Brumm, H. Birds and anthropogenic noise: Are urban songs adaptive? Am. Nat. 2010, 176, 465-475. [CrossRef] [PubMed]

112. Slabbekoorn, H.; Ripmeester, E.A.P. Birdsong and anthropogenic noise: Implications and applications for conservation. Mol. Ecol. 2008, 17, 72-83. [CrossRef] [PubMed]

113. Slabbekoorn, H.; Boer-Visser, A. Cities change the songs of birds. Curr. Biol. 2006, 16, 2326-2331. [CrossRef] [PubMed]

114. Laiolo, P. The Rufous-Collared sparrow (Zonotrichia capensis) utters higher frequency songs in urban habitats. Rev. Catalana d'Ornitologia 2011, 27, 25-30.

115. Luther, D.A.; Derryberry, E.P. Birdsongs keep pace with city life: Changes in song over time in an urban songbird affects communication. Anim. Behav. 2012, 83, 1059-1066. [CrossRef]

116. Job, J.R.; Kohler, S.L.; Gill, S.A. Song adjustments by an open habitat bird to anthropogenic noise, urban structure, and vegetation. Behav. Ecol. 2016, 27, 1734-1744. [CrossRef]

117. LaZerte, S.E.; Otter, K.A.; Slabbekoorn, H. Mountain chickadees adjust songs, calls and chorus composition with increasing ambient and experimental anthropogenic noise. Urban Ecosyst. 2017, 20, 989-1000. [CrossRef]

118. Cardoso, G.C.; Hu, Y.; Francis, C.D. The comparative evidence for urban species sorting by anthropogenic noise. $R$ Soc. Open Sci. 2018, 5, 172059. [CrossRef]

119. Moiron, M.; González-Lagos, C.; Slabbekoorn, H.; Sol, D. Singing in the city: High song frequencies are no guarantee for urban success in birds. Behav. Ecol. 2015, 26, 843-850. [CrossRef]

120. Luther, D.A.; Phillips, J.; Derryberry, E.P. Not so sexy in the city: Urban birds adjust songs to noise but compromise vocal performance. Behav. Ecol. 2016, 27, 332-340. [CrossRef]

121. Narango, D.L.; Rodewald, A.D. Urban-associated drivers of song variation along a rural-urban gradient. Behav. Ecol. 2016, 27, 608-616. [CrossRef]

122. Phillips, J.N.; Derryberry, E.P. Urban sparrows respond to a sexually selected trait with increased aggression in noise. Sci. Rep. 2018, 8, 7505. [CrossRef] [PubMed]

123. Ríos-Chelén, A.A.; Quirós-Guerrero, E.; Gil, D.; Macías-Garcia, C. Dealing with urban noise: Vermilion flycatchers sing longer songs in noisier territories. Behav. Ecol. Sociobiol. 2013, 67, 145-152. [CrossRef]

124. Lowry, H.; Lill, A.; Wong, B.B.M. How noisy Does a noisy miner have to be? Amplitude adjustments of alarm calls in an avian urban 'adapter'. PLoS ONE 2011, 7, e29960. [CrossRef] [PubMed]

125. Potvin, D.A.; Mulder, R.A. Immediate, independent adjustment of call pitch and amplitude in response to varying background noise by Silvereyes (Zosterops lateralis). Behav. Ecol. 2013, 24, 1363-1368. [CrossRef]

126. Knight, C.R.; Swaddle, J.P. Eastern Bluebirds alter their song in response to anthropogenic changes in the acoustic environment. Integr. Comp. Biol. 2015, 55, 418-431. [CrossRef]

127. Díaz, M.; Parra, A.; Gallardo, C. Serins respond to anthropogenic noise by increasing vocal activity. Behav. Ecol. 2011, 22, 332-336. [CrossRef]

128. Redondo, P.; Barrantes, G.; Sandoval, L. Urban noise influences vocalization structure in the House wren (Troglodytes aedon). Ibis 2013, 155, 621-625. [CrossRef]

129. Moseley, D.L.; Phillips, J.N.; Derryberry, E.P.; Luther, D.A. Evidence for differing trajectories of songs in urban and rural populations. Behav. Ecol. 2019, 30, 1734-1742. [CrossRef]

130. Potvin, D.A.; Mulder, R.A.; Parris, K.M. Silvereyes decrease acoustic frequency but increase efficacy of alarm calls in urban noise. Anim. Behav. 2014, 98, 27-33. [CrossRef]

131. Potvin, D.A.; Parris, K.M.; Mulder, R.A. Geographically pervasive effects of urban noise on frequency and syllable rate of songs and calls in Silvereyes (Zosterops lateralis). Proc. R. Soc. B Biol. Sci. 2011, 278, 2464-2469. [CrossRef] [PubMed]

132. Seger-Fullam, K.D.; Rodewald, A.D.; Soha, J.A. Urban noise predicts song frequency in Northern cardinals and American robins. Bioacoustics 2011, 20, 267-276. [CrossRef]

133. Shannon, G.; McKenna, M.F.; Angeloni, L.M.; Crooks, K.R.; Fristrup, K.M.; Brown, E.; Warner, K.A.; Nelson, M.D.; White, C.; Briggs, J.; et al. A synthesis of two decades of research documenting the effects of noise on wildlife. Biol. Rev. 2016, 91, 982-1005. [CrossRef] [PubMed]

134. Fernández-Juricic, E.; Poston, R.; Collibus, K.D.; Morgan, T.; Bastain, B.; Martin, C.; Jones, K.; Treminio, R. Microhabitat selection and singing behavior patterns of male house finches (Haemorhous mexicanus) in urban parks in a heavily urbanized landscape in the western U.S. Urban Habitats 2005, 3, 49-69.

135. Badyaev, A.V.; Young, R.L.; Oh, K.P.; Addison, C. Evolution on a local scale: Developmental, functional, and genetic bases of divergence in bill form and associated changes in song structure between adjacent habitats. Evolution 2008, 62, 1951-1964. [CrossRef] [PubMed] 
136. Nordt, A.; Klenke, R. Sleepless in town-Drivers of the temporal shift in dawn song in urban European blackbirds. PLoS ONE 2013, 8, e71476. [CrossRef]

137. Dorado-Correa, A.M.; Rodríguez-Rocha, M.; Brumm, H. Anthropogenic noise, but not artificial light levels predict song behavior in an equatorial bird. $R$ Soc. Open Sci. 2016, 3, 160231. [CrossRef]

138. Kempenaers, B.; Borgström, P.; Loës, P.; Schlicht, E.; Valcu, M. Artificial night lighting affects dawn song, extra-pair siring success, and lay date in songbirds. Curr. Biol. 2010, 20, 1735-1739. [CrossRef]

139. Randler, C. Disturbances by dog barking increase vigilance in coots Fulica atra. Eur. J. Wildl. Res. 2006, 52, 265-270. [CrossRef]

140. Bonnington, C.; Gaston, K.J.; Evans, K.L. Fearing the feline: Domestic cats reduce avian fecundity through trait-mediated indirect effects that increase nest predation by other species. J. Appl. Ecol. 2013, 50, 15-24. [CrossRef]

141. Rebolo-Ifrán, N.; Carrete, M.; Sanz-Aguilar, A.; Rodríguez-Martínez, S.; Cabezas, S.; Marchant, T.A.; Bortolotti, G.R.; Tella, J.L. Links between fear of humans, stress and survival support a non-random distribution of birds among urban and rural habitats. Sci. Rep. 2015, 5, 13723. [CrossRef] [PubMed]

142. Samia, D.S.M.; Nakagawa, S.; Nomura, F.; Rangel, T.F.; Blumstein, D.T. Increased tolerance to humans among disturbed wildlife. Nat. Commun. 2015, 6, 8877. [CrossRef] [PubMed]

143. Eötvösa, C.B.; Magura, T.; Lövei, G.L. A meta-analysis indicates reduced predation pressure with increasing urbanization. Landsc. Urban Plan 2018, 180, 54-59. [CrossRef]

144. Weaver, M.; Ligon, R.A.; Mousel, M.; McGraw, K.J. Avian anthrophobia? Behavioral and physiological responses of house finches (Haemorhous mexicanus) to human and predator threats across an urban gradient. Landsc. Urban Plan 2018, 179, 46-54. [CrossRef]

145. McGiffin, A.; Lill, A.; Beckman, J.; Johnstone, C.P. Tolerance of human approaches by Common mynas along an urban-rural gradient. EMU Austral Ornithol. 2013, 113, 154-160. [CrossRef]

146. Møller, A.P.; Grim, T.; Ibáñez-Álamo, J.D.; Markó, G.; Tryjanowski, P. Change in flight initiation distance between urban and rural habitats following a cold winter. Behav. Ecol. 2013, 24, 1211-1217. [CrossRef]

147. Møller, A.P.; Díaz, M.; Flensted-Jensen, E.; Grim, T.; Ibáñez-Álamo, J.D.; Jokimäki, J.; Mänd, R.; Markó, G.; Tryjanowski, P. Urbanized birds have superior establishment success in novel environments. Oecologia 2015, 178, 943-950. [CrossRef]

148. Vines, A.; Lill, A. Boldness and urban dwelling in little ravens. Wildl. Res. 2014, 42, 590-597. [CrossRef]

149. Gravolin, I.; Key, M.; Lill, A. Boldness of urban Australian magpies and local traffic volume. Avian Biol. Res. 2014, 7, 244-250. [CrossRef]

150. Samia, D.S.M.; Blumstein, D.T.; Díaz, M.; Grim, T.; Ibáñez-Álamo, J.D.; Jokimäki, J.; Tätte, K.; Markó, G.; Tryjanowski, P.; Møller, A.P. Rural-urban differences in escape behavior of European birds across a latitudinal gradient. Front. Ecol. Evol. 2017, 5, 66. [CrossRef]

151. Morelli, F.; Mikula, P.; Benedetti, Y.; Bussière, R.; Jerzak, L.; Tryjanowski, P. Escape behavior of birds in urban parks and cemeteries across Europe: Evidence of behavioral adaptation to human activity. Sci. Total Environ. 2018, 631, 803-810. [CrossRef] [PubMed]

152. Biondi, L.M.; Fuentes, G.M.; Córdoba, R.S.; Bó, M.S.; Cavalli, M.; Paterlini, C.A.; Castano, M.V.; García, G.O. Variation in boldness and novelty response between rural and urban predatory birds: The Chimango Caracara (Milvago chimango) as study case. Behav. Process 2020, 173, 104064. [CrossRef] [PubMed]

153. Fleming, P.A.; Bateman, P.W. Scavenging opportunities modulate escape responses over a small geographic scale. Ethology 2017, 123, 205-212. [CrossRef]

154. Feng, C.; Liang, W. Behavioral responses of black-headed gulls (Chroicocephalus ridibundus) to artificial provisioning in China. Glob. Ecol. Conserv. 2020, 21, e00873. [CrossRef]

155. Pavlova, O.; Wronski, T. City gulls and their rural neighbours: Changes in escape and agonistic behaviour along a rural-to-urban gradient. In Advances in Environmental Research; Nova Science Publishers, Inc.: Hauppauge, NY, USA, 2020.

156. Møller, A.P. Interspecific variation in fear responses predicts urbanization in birds. Behav. Ecol. 2010, 21, 365-371. [CrossRef]

157. Kitchen, K.; Lill, A.; Price, M. Tolerance of human disturbance by urban magpie-larks. Aust. Field Ornithol. 2010, $27,1$.

158. Gendall, J.; Lill, A.; Beckman, J. Tolerance of disturbance by humans in long-time resident and recent colonist urban doves. Avian Res. 2015, 6, 7. [CrossRef]

159. Sol, D.; Maspons, J.; Gonzalez-Voyer, A.; Morales-Castilla, I.; Garamszegi, L.Z.; Møller, A.P. Risk-taking behavior, urbanization and the pace of life in birds. Behav. Ecol. Sociobiol. 2018, 72, 59-66. [CrossRef]

160. Sol, D.; Griffin, A.S.; Bartomeus, I.; Boyce, H. Exploring or avoiding novel food resources? The novelty conflict in an invasive bird. PLoS ONE 2011, 6, e19535. [CrossRef]

161. Shanahan, D.F.; Strohbach, M.W.; Warren, P.S.; Fuller, R.A. The challenges of urban living. In Avian Urban Ecology; Diego, G., Henrik, B., Eds.; Oxford University Press: Oxford, UK, 2014; pp. 3-20.

162. Griffin, A.S.; Netto, K.; Peneaux, C. Neophilia, innovation and learning in an urbanized world: A critical evaluation of mixed findings. Curr. Opin. Behav. Sci. 2017, 17, 15-22. [CrossRef]

163. Seress, G.; Bókony, V.; Heszberger, J.; Liker, A. Response to predation risk in urban and rural house sparrows. Ethology 2011, 117, 896-907. [CrossRef]

164. Møller, A.P.; Ibáñez-Álamo, J.D. Escape behavior of birds provides evidence of predation being involved in urbanization. Anim. Behav. 2012, 84, 341-348. [CrossRef] 
165. Tryjanowski, P.; Møller, A.P.; Morelli, F.; Biaduń, W.; Brauze, T.; Ciach, M.; Czechowski, P.; Czyż, S.; Dulisz, B.; Goławski, A.; et al. Urbanization affects neophilia and risk-taking at bird-feeders. Sci. Rep. 2016, 6, 28575. [CrossRef] [PubMed]

166. Audet, J.N.; Ducatez, S.; Lefebvre, L. The town bird and the country bird: Problem solving and immune-competence vary with urbanization. Behav. Ecol. 2016, 27, 637-644. [CrossRef]

167. Papp, S.; Vincze, E.; Preiszner, B.; Liker, A.; Bókony, V. A comparison of problem-solving success between urban and rural house sparrows. Behav. Ecol. Sociobiol. 2015, 9, 471-480. [CrossRef]

168. Ducatez, S.; Audet, J.N.; Ros, J.; Kayello, R.L.; Lefebvre, L. Innovativeness and the effects of urbanization on risk-taking behaviors in wild Barbados birds. Anim. Cogn. 2017, 20, 33-42. [CrossRef]

169. Spelt, A.; Soutar, O.; Williamson, C.; Memmott, J.; Shamoun-Baranes, J.; Rock, P.; Windsor, S. Urban gulls adapt foraging schedule to human-activity patterns. Ibis 2020, 163, 274-282. [CrossRef]

170. Yosef, R.; Zduniak, P.; Poliakov, Y.; Fingerman, A. Behavioural and reproductive flexibility of an invasive bird in an arid zone: A case of the Indian House Crow (Corvus splendens). J. Arid Environ. 2019, 168, 56-58. [CrossRef]

171. Bókony, V.; Kulcsár, A.; Tóth, Z.; Liker, A. Personality traits and behavioral syndromes in differently urbanized populations of house sparrows (Passer domesticus). PLoS ONE 2012, 7, e36639. [CrossRef]

172. Kozlovsky, D.Y.; Weissgerber, E.A.; Pravosudov, V.V. What makes specialized food-caching mountain chickadees successful city slickers? Proc. R. Soc. B Biol. Sci. 2017, 284, 20162613. [CrossRef]

173. Greggor, A.L.; Clayton, N.S.; Fulford, A.J.C.; Thornton, A. Street smart: Faster approach towards litter in urban areas by highly neophobic corvids and less fearful birds. Anim. Behav. 2016, 117, 123-133. [CrossRef]

174. Lill, A.; Hales, E. Behavioral and ecological keys to urban colonization by Little Ravens (Corvus mellori). Open Ornithol. J. 2015, 8, 22-31. [CrossRef]

175. Campbell, M. An animal geography of avian feeding habits in Peterborough, Ontario. Area 2008, 40, 472-480. [CrossRef]

176. Evans, J.; Boudreau, K.; Hyman, J. Behavioral syndromes in urban and rural populations of Song sparrows. Ethology 2010, 116, 588-595.

177. Scales, J.; Hyman, J.; Hughes, M. Behavioral syndromes break down in urban Song sparrow populations. Ethology 2011, 117, 887-895. [CrossRef]

178. Hasegawa, M.; Ligon, R.A.; Giraudeau, M.; Watanabe, M.; McGraw, K.J. Urban and colorful male house finches are less aggressive. Behav. Ecol. 2014, 25, 641-649. [CrossRef]

179. Hardman, S.I.; Dalesman, S. Repeatability and degree of territorial aggression differs among urban and rural Great tits (Parus major). Sci. Rep. 2018, 8, 5042. [CrossRef]

180. Galbreath, D.M.; Ichinose, T.; Furutani, T.; Yan, W.; Higuchi, H. Urbanization and its implications for avian aggression: A case study of urban black kites (Milvus migrans) along Sagami Bay in Japan. Landsc. Ecol. 2014, 29, 169-178. [CrossRef]

181. McClelland, S.C.; Ribeiro, R.D.; Mielke, H.W.; Finkelstein, M.E.; Gonzales, C.R.; Jones, J.A.; Komdeur, J.; Derryberry, E.; Saltzberg, E.B.; Karubian, J. Sub-lethal exposure to lead is associated with heightened aggression in an urban songbird. Sci. Total Environ. 2019, 654, 593-603. [CrossRef]

182. Kunca, T.; Yosef, R. Differential nest-defense to perceived danger in urban and rural areas by female Eurasian sparrowhawk (Accipiter nisus). PeerJ 2016, 4, e2070. [CrossRef]

183. Senar, J.C.; Garamszegi, L.Z.; Tilgar, V.; Biard, C.; Moreno-Rueda, G.; Salmón, P.; Rivas, J.; Sprau, P.; Dingemanse, N.J.; Charmantier, A.; et al. Urban Great tits (Parus major) show higher distress calling and pecking rates than rural birds across Europe. Front. Ecol. Evol. 2017, 5, 163. [CrossRef]

184. Minias, P.; Jedlikowski, J.; Włodarczyk, R. Development of urban behavior is associated with time since urbanization in a reed-nesting waterbird. Urban Ecosyst. 2018, 21, 1021-1028. [CrossRef]

185. Alberti, M.; Marzluff, J.; Hunt, V.M. Urban driven phenotypic changes: Empirical observations and theoretical implications for eco-evolutionary feedback. Philos. Trans. R. Soc. B 2017, 372, 20160029. [CrossRef]

186. Capilla-Lasheras, P.; Dominoni, D.M.; Babayan, S.A.; O’Shaughnessy, P.J.; Mladenova, M.; Woodford, L.; Pollock, C.J.; Barr, T.; Baldini, F.; Helm, B. Elevated immune gene expression is associated with poor reproductive success of urban Blue tits. Front. Ecol. Evol. 2017, 5, 64. [CrossRef]

187. Mueller, J.C.; Partecke, J.; Hatchwell, B.J.; Gaston, K.J.; Evans, K.L. Candidate gene polymorphisms for behavioral adaptations during urbanization in blackbirds. Mol. Ecol. 2013, 22, 3629-3637. [CrossRef]

188. Partecke, J.; Gwinner, E.; Bensch, S. Is urbanization of European blackbirds (Turdus merula) associated with genetic differentiation? J. Ornithol. 2006, 147, 549-552. [CrossRef]

189. Richards, D.R.; Passy, P.; Oh, R.R. Impacts of population density and wealth on the quantity and structure of urban green space in tropical Southeast Asia. Landsc. Urban Plan 2017, 157, 553-560. [CrossRef]

190. Harper, G.A.; Bunbury, N. Invasive rats on tropical islands: Their population biology and impacts on native species. Glob. Ecol. Conserv. 2015, 3, 607-627. [CrossRef]

191. Ferenc, M.; Sedláček, O.; Fuchs, R. How to improve urban greenspace for woodland birds: Site and local-scale determinants of bird species richness. Urban Ecosyst. 2014, 17, 625-640. [CrossRef]

192. Moreno-Mateos, D.; Rey Benayas, J.M.; Pérez-Camacho, L.; Montaña, E.D.L.; Rebollo, S.; Cayuela, L. Effects of land use on nocturnal birds in a Mediterranean agricultural landscape. Acta Ornithol. 2011, 46, 173-182. [CrossRef] 